NBER WORKING PAPER SERIES

\title{
ONE STEP AT A TIME: \\ THE EFFECTS OF AN EARLY LITERACY TEXT MESSAGING PROGRAM FOR PARENTS OF PRESCHOOLERS
}

\author{
Benjamin N. York \\ Susanna Loeb \\ Working Paper 20659 \\ http://www.nber.org/papers/w20659 \\ NATIONAL BUREAU OF ECONOMIC RESEARCH \\ 1050 Massachusetts Avenue \\ Cambridge, MA 02138
}

November 2014, Revised March 2018

The authors would like to give special thanks to Carla Bryant, Chief of Early Education of San Francisco Unified School District, and her team, for the many ways in which they supported this study. They also thank Helen Maniates, Assistant Professor of Teacher Education at the University of San Francisco, Molly Wertz, Executive Director of Raising A Reader in San Francisco, Alameda and Contra Costa Counties, and various team members of Jumpstart Northern California, including Jennifer Curran and Catherine Aranda, for their feedback on READY4K! text messages. This research was supported by the Silver Giving Foundation, the Evelyn and Walter Haas, Jr. Fund, and the Institute of Education Sciences (IES), United States (U.S.) Department of Education, through Grant R305B090016 to Stanford University. The opinions expressed are those of the authors and do not reflect the views of the Silver Giving Foundation, the Evelyn and Walter Haas, Jr. Fund, IES, the U.S. Department of Education, or the National Bureau of Economic Research. This randomized controlled trial (RCT) was registered in the American Economic Association Registry (RCT ID AEARCTR-0000536).

NBER working papers are circulated for discussion and comment purposes. They have not been peer-reviewed or been subject to the review by the NBER Board of Directors that accompanies official NBER publications.

(C) 2014 by Benjamin N. York and Susanna Loeb. All rights reserved. Short sections of text, not to exceed two paragraphs, may be quoted without explicit permission provided that full credit, including $\odot$ notice, is given to the source. 
One Step at a Time: The Effects of an Early Literacy Text Messaging Program for Parents of Preschoolers

Benjamin N. York and Susanna Loeb

NBER Working Paper No. 20659

November 2014, Revised March 2018

JEL No. I1,I10,I12,I2,I20,I25

\begin{abstract}
Large systematic differences in young children's home learning experiences have long-term economic consequences. Many parenting programs place significant demands on parents' time and inundate parents with information. This study evaluates the effects of READY4K!, an eightmonth-long text-messaging intervention for parents of preschoolers that targets the behavioral barriers to engaged parenting. We find that READY4K! increased parental involvement at home and school by 0.15 to 0.29 standard deviations, leading to child gains in early literacy of about 0.11 standard deviations. The results point to the salience of behavioral barriers to parenting and the potential for low-cost interventions to reduce these barriers.
\end{abstract}

\author{
Benjamin N. York \\ ParentPowered Technologies \\ 10 Mulberry Ct. \#3 \\ Belmont, CA 94002 \\ ben.york@parentpowered.com \\ Susanna Loeb \\ 524 CERAS, 520 Galvez Mall \\ Stanford University \\ Stanford, CA 94305 \\ and NBER \\ sloeb@stanford.edu
}




\section{Introduction}

The home learning experiences of young children vary dramatically (Bradley et al. 2001). Hart and Risley (1995), for example, find that by the age of four, children in low-income families hear about 30 million fewer words than children in "professional families." Parenting interventions represent one strategy for addressing such differences, yet to date, only a small number of programs have shown positive effects on parents or their children (Duncan, Ludwig, and Magnuson 2010). Even the most promising interventions, including pediatric clinic-based programs and home visitation programs have meaningful limitations such as access and cost. Most existing interventions try to rapidly change complex parenting behaviors through a small number of time- and information-intensive parent education sessions.

An alternative to existing approaches is to break down the complexity of parenting into small steps that are easy-to-achieve, and provide encouragement, support, and reinforcement to parents over extended periods of time. Given its widespread use, extremely low cost, and ease of scalability, text messaging is a promising vehicle for implementing this strategy. Over 96 percent of American adults under the age of 50 have cell phones, 98 percent of cell phone owners can access texts, and text messages have a 95 percent open rate (Ehrlich 2013; Anderson 2015). Black and Hispanic adults, who often exhibit the highest dropout rates in parenting programs, send texts even more frequently than their white counterparts (Zickuhr and Smith 2012). Texting has proven to be effective in behavior change applications. In education, Castleman and Page (2015) find positive effects of a texting program for recent high school graduates designed to curb summer "melt," which occurs when college-intending graduates fail to matriculate in college the year after high school. Similarly, Bergman (2016) finds that high school students whose parents received messages about their missing work and grades had improved by 0.19 standard deviations (SD). 
This study adds to research on both parenting and behavioral interventions by evaluating the effects of an eight-month-long text-messaging program for parents of preschoolers called READY4K!, designed to help them support their children's development. During the 2013-14 and 2015-16 school years, we conducted randomized controlled trials (RCTs) of the program in San Francisco Unified School District (SFUSD). Between the two years 1,031 parents and guardians agreed to participate in the study, and we randomly selected half to receive the program. Each week, these parents received three texts about an academic skill or set of skills: a "FACT" text designed to inform and motivate parents; a "TIP" text that aimed to minimize the cognitive, emotional, and time burdens of engaged parenting by providing parents with highly-specific activities that build on existing family routines; and a "GROWTH" text, which provided parents with encouragement and reinforcement as well as a follow-up tip. About every two weeks, we sent one "placebo" text to parents in the control group, often pertaining to the district's kindergarten enrollment process or required vaccinations.

We find strong evidence that parents in the treatment group used the tips and found the program to be helpful. For example, treatment group parents found READY4K! texts to be 0.41 SD more helpful than control group parents $(\mathrm{p}<0.01)$. In addition, treatment parents reported engaging in more home literacy activities with their children, ranging from pointing out rhyming words to concepts of print like showing their children the different parts of a book- an average of $0.16 \mathrm{SD}(\mathrm{p}<0.10)$. According to teachers, parents in the treatment group more frequently asked questions about their children's school experiences than the control group parents - effects of up to $0.21(0.14$ average $)$ SD $(\mathrm{p}<0.05)$. Increases in parental involvement at home and school translated into learning gains for children, as students whose parents received READY4K! texts scored an average of $0.11 \mathrm{SD}(\mathrm{p}<0.05)$ higher on a spring early literacy assessment. Children who 
scored below the median of the baseline skills particularly benefited from the intervention with an increase in literacy skills of $0.31 \mathrm{SD}(\mathrm{p}<0.01)$.

The remainder of this paper proceeds as follows. In Section 2, we review research on the behavioral barriers to engaged parenting, as well as on parenting and text messaging interventions. Section 3 describes study procedures. In Section 4, we present study results. We conclude this paper in Section 5 with a discussion of the findings.

\section{Literature Review}

Virtually all parents want their children to succeed in school (Stevenson, Chen, and Uttal 1990), yet some parents provide their children with comparatively more support. For example, economically disadvantaged and wealthy parents exhibit large and systematic differences in parenting practices, though there are clear variations within economic groups as well. From birth to age two, non-poor children are more likely than poor children to be caressed, kissed, or hugged by their mother, and they are less likely to be spanked. Non-poor birth-to-two-year-olds also have greater access to children's books and are more likely to be read to than their poor counterparts. These disparities have significant consequences, as children who experience responsive and stimulating parental care tend to score higher on assessments of motor, social, emotional, literacy, and numeracy skills than those who do not (Bradley et al. 2001; NICHD Early Child Care Research Network 2006; Melhuish et al. 2008). Skill gaps that develop early in life are difficult to overcome and have significant negative implications for later life economic outcomes (Heckman 2006).

Given that most parents want their children to succeed in school, why are some parents more involved in their children's learning? Unequal access to resources - such as toys, books, free time, parks, and libraries - is clearly a part of the answer to this question (Costello et al. 2003; Riccio et al. 2013). This study, however, focuses on behavioral barriers to involved parenting that 
are not included in most basic economic models of utility maximization under a budget constraint. These factors may be easier and more cost effective to address through policies or interventions.

We identify at least four sets of barriers that may cause families to underinvest in the academic development of their children. Each component of the READY4K! program is designed to address at least one of these barriers. First, parents may have insufficient information regarding which skills their children should be learning during the prekindergarten years and the importance of those skills for the long-term success of their children. Second, engaged parenting is a cognitively complex and broad endeavor. In the face of this daunting task, parents may make suboptimal choices regarding the investment into their children's academic development. Third, parenting requires continual attention over long periods of time and such tasks are often difficult to sustain. Fourth, the benefits of current investments in early childhood education are distal and uncertain. Time-inconsistent preferences may cause parents to substitute attention to more immediately gratifying activities that do not have the same long-term benefits for their children.

Imperfect information has been studied in a variety of contexts, but may be especially salient in early childhood. Only recently have researchers quantified the long-term benefits of quality early education experiences (Heckman 2006). Some parents may not have information about the importance of parenting or productive parenting practices, and fail to provide their children with an adequate level of support or the right types of support. Imperfect information has been studied in other educational contexts with mixed results. Avery and Kane (2004) and Grodsky and Jones (2007), for example, find little evidence that students or parents lacking information about the costs and benefits of college explains the socioeconomic stratification of college attendance. Other studies find that the provision of information impacts school choices and student 
outcomes (Hastings and Weinstein 2008; Valant and Loeb 2014). READY4K! reduces information asymmetries by sending texts that detail the importance of each week's skill.

Even if parents have accurate information and knowledge, the limited information processing capabilities of the human mind (Simon 1955) may cause parents to underinvest in their children. In the face of cognitively demanding tasks - such as tasks requiring a substantial amount of choice, and continuous, on-going tasks - individuals tend to make choices based on faulty heuristics or they avoid making decisions altogether (Mullainathan and Thaler 2000). The cognitive demands of parenting are high, as each day parents must make decisions about what to say, do, and provide to their children in every situation. Making choices about activities to support child development may be particularly daunting for parents, given that many of the skills required to be successful in school are outside of parents' area of expertise (e.g., literacy, numeracy, and socio-emotional skills).

Ample research provides evidence of suboptimal behavior (e.g., poor decision making) in the face of high cognitive demand (bounded rationality). For example, one study underscoring the difficulty of tasks that require substantial choice finds that reducing the selection of jams offered to consumers from 24 to six varieties, all equally appealing, increases the likelihood of a jam purchase by ten-fold (Iyengar and Lepper 2000). In education, a random assignment study of simplifying the college enrollment process finds that students of low- to moderate-income families who received assistance filling out the Free Application for Federal Student Aid, along with information about their eligibility for aid and local post-secondary options, were substantially more likely to submit the aid application and enroll in college the following fall than students in families that only received information (Bettinger et al. 2012). Poverty may also exacerbate the cognitive demand barrier. As people living in poverty focus on meeting daily financial challenges, such as 
buying food and paying rent, less cognitive capacity remains for completing other complex tasks such as parenting. Researchers have shown the existence of the scarcity phenomenon both in the laboratory and in contexts such as farming (Shah, Mullainathan, and Shafir 2012; Mani et al. 2013). READY4K! reduces the cognitive complexity of developing literacy skills by providing tips on activities parents can employ during regular routines using common household objects.

Increasing evidence also points to the possibility that limits to attention can lead to suboptimal behavior (Karlan et al. 2010). Given the significant demands on most parents' time, parents likely have particularly limited attention. A single mother, for instance, might have the goal of providing daily test preparation support to her child for an exam to be administered in a month, but may be preoccupied by the day-to-day rigors of being a parent (e.g., working one or more jobs, shopping for groceries, paying the bills, house chores, and bathing, dressing, feeding, transporting, and entertaining her child or children) and forget to help her child until the final days leading up to the assessment, ultimately underinvesting in the child's preparation relative to her initial preference. A series of randomized experiments finds that sending regular reminders to new savings account holders improves their saving behavior, providing evidence for the importance of limited attention (Karlan et al. 2010). With each text, READY4K! redirects parent attention to the important task of literacy development.

Finally, time-inconsistent preferences, or self-control problems (DellaVigna 2009), are likely most germane to parents. In parenting, a potentially significant source of self-control problems is delayed gratification. Although many parents derive pleasure from doing activities with their children, the benefits of activities that will increase children's school readiness skills are not always evident and parents may prefer to do other activities with their children that are more familiar or will be sure to make their children happy. Moreover, school readiness-building 
activities generally do not lead to immediate gains in child development, meaning that parents must wait for the satisfaction that they receive from engaging in these activities. Parental involvement also requires parents to forego personal activities with immediate rewards, such as talking to a friend on the phone or going for walk, and thus has potentially significant timing hurdles. Many people tend to do too little when gratification is delayed (Thaler and Sunstein 2008). Bandura and Schunk (1981) showed that reframing a large distal goal into a series of small proximal goals increased students' confidence and improved test scores. READY4K! mitigates time-inconsistent preferences by repeatedly encouraging parents and highlighting the more proximal goal of success in kindergarten.

Many parenting programs try to quickly change complex parenting behaviors through a short series of time-intensive parenting information sessions. This strategy has proven to be largely ineffective, especially over the long run (Duncan, Ludwig, and Magnuson 2010). This lack of effectiveness is not surprising given that behavioral hurdles to parenting are generally not alleviated and, in fact, may be increased by common approaches that place significant demands on parents' time and inundate parents with information.

An alternative strategy that has shown promise is to target parents' home literacy practices by leveraging children's visits to the doctor's office. Pediatric clinic-based programs provide parents with information on the importance of literacy development as well as books and other resources. These relatively inexpensive interventions concentrate on information asymmetries and have correlated with improvements in literacy practices among low-income, black, and Hispanic parents (Golova et al. 1999; Needlman et al. 2005; Blom-Hoffman et al. 2007; Zuckerman 2009). Program participation generally predicts children's language development (Sharif, Rieber, and 
Ozuah 2002). One such program, the Reach out and Read (ROR) program, has received a particularly high level of attention in the literature (Mendelsohn et al. 2001).

Some childcare centers and elementary schools have carried out similar family-based home literacy interventions (e.g., Whitehurst et al. 1994; Jordan, Snow, and Porche 2000). Recent metaanalyses of these programs find that they are associated with small but significant short-term gains for young children (Manz et al. 2010; Reese, Sparks, and Leyva 2010). These studies again concentrate on information asymmetries by providing parents training on how to read with their children. For example, a random assignment study of a reading program that teaches parents dialogic reading techniques such as asking open-ended questions finds positive treatment effects on children's writing, language, and print concepts skills (Whitehurst et al. 1994).

While clinic- and school-based programs show promise, they have a number of limitations. Many of the benefits of clinic-based interventions occur during visits, which are often infrequent. The shortcomings of school-based programs are even greater, largely driven by the time and effort demands school-based programs place on parents. For instance, the overall participation rate in a study of ParentCorps, which consists of 13 school-based, two hour-long parent and child sessions, was 42 percent, and the average number of sessions attended by treatment group parents was less than six (Brotman et al. 2011). Dropout rates in center-based programs are often high, and it is often the parents who could benefit the most from support who drop out (Prinz and Miller 1994).

The ubiquity of technology has provided new opportunities to field interventions that address these behavioral barriers. Interventions that depend in part, or solely, on texting have shown promise. Castleman and Page (2015) evaluate a texting program for recent high school graduates designed increase college enrollment. The program, which was delivered between early June and mid-August, consists of a series of 10 texts messages to students and their parents, sent 
roughly over five-day intervals. The messages addressed limited attention by reminding students and their parents about tasks required by the students' intended college such as completing important paperwork. They also prompt students and parents to ask for additional assistance if needed, potentially reducing the cognitive demand of these tasks. The study finds that students were roughly three percentage points more likely to enroll at two-year institutions and that texting was particularly effective for students with low access to college-planning supports. Another notable experimental texting study sent parents or guardians of high school students messages for six months about students' missing assignments such as homework, classwork, exams and grades (Bergman 2016). This study mainly focuses on parental information asymmetries and the limited attention of parents and finds positive treatment effects on attendance, assignment completion, behavior, and grade point average, and some evidence of effects on math test scores.

Most relevant for this study, Mayer at al. (2015) provide parents of children in Head Start with tablets with which they operationalize behavioral economics principals to increase the number of books children read at home. The Parents and Children Together (PACT) intervention requires that parents set a goal around the number of books children read in the home. This soft commitment device is supported by text messages that remind and encourage the parents, which address limited attention and time-inconsistent preferences. The authors found that treated parents read 88 minutes more with their children a week. They attribute the lower amount of reading in the control group to the fact that parents heavily discounted the future.

To the best of our knowledge, there have been no attempts to use texting as the sole vehicle to leverage multiple behavioral economics principals in an effort to encourage parents to more actively engage in academics with their children in the home. In this study, we evaluate the impact of READY4K!, an early literacy-focused text messaging program for parents of preschoolers that 
does just that by breaking down parenting activities into small steps that are relatively easy to achieve in a highly-structured fashion.

\section{Procedures}

\section{3a. The Intervention}

READY4K! is an eight-month-long text messaging program for parents of four year olds designed to help them support their children's academic development. This study reports on the results of providing the program to two cohorts of prekindergarten families in the San Francisco Unified School District (SFUSD). During the 2013-2014 school year we randomly selected participants to receive a program dedicated solely to improving literacy skills. During the 20152016 school year we randomly selected families to receive a program that supported the literacy, math, and socio-emotional development of their children. Though the content of the program differs between years, the structure of the program remains identical and we cull on the same behavioral economics and education theories to change parental habits. Both programs draw on research in academic development (e.g., California Department of Education 2008; Lonigan and Shanahan 2009), academic-related parenting practices (e.g., Reese, Sparks, and Leyva 2010), and behavioral economics (e.g., Simon 1955). Both programs are linked to the California Preschool Learning Foundations and are structured as a spiral curriculum. They start with simple topics and gets progressively more advanced over time. Topics are re-introduced throughout the year for reinforcement. In describing the program, we concentrate on the literacy texts because they are common between years. Information on the math and socio-emotional texts are available on request.

Parents in the treatment group received three READY4K! texts messages per week during the school year (starting in October and ending in May), each week addressing a particular set of 
skills. On Mondays, they received "FACT" texts, designed to inform and motivate parents by highlighting the importance of a particular skill or set of skills. On Wednesdays, they received "TIP" texts, designed to minimize the cognitive, emotional, and time burdens of engaged parenting. These texts include short, simple, and highly specific activities for parents to do with their children that build on existing family routines. To maximize the likelihood of uptake, we aimed to make the activities fun for parents and their children. On Fridays, parents received "GROWTH" texts, which provide encouragement, and extend the Wednesday tips. The following is an example week of texts:

FACT: Letters are the building blocks of written language. Children need to know the letters to learn how to read \& write.

TIP: Point out the first letter in your child's name in magazines, at the store \& on signs. Have your child try. Make it a game. Who can find the most?

GROWTH: Keep pointing out letters. You're preparing your child 4K! Now when you point out a letter, ask: What sound does it make?

Overall, literacy texts cover a wide range of skills and related parenting practices, including: upper- and lower-case letter recognition, letter sound awareness, beginning sound awareness, rhyme awareness, name writing, concepts of print, story comprehension, vocabulary development, listening to and singing songs, self-narration, parent-child conversations, and establishing high-quality parent-child book reading routines. Math texts cover topics such as: counting, number recognition, shapes, sorting, patterns, addition, subtraction, and comparisons of size. Finally, socio-emotional texts concentrate on identifying emotions, identifying their causes 
and consequences, building emotion regulation, perseverance, sharing, and turn-taking. Parents chose to receive texts in English, Spanish, or Chinese.

In the first year of the program, we integrated text messages that emphasized parental involvement at school. The following text, which we sent during a week about concepts of print, is one example:

TIP: Ask the teacher about your child's knowledge of concepts of print. Concepts of print include knowing how book are organized \& that words have meaning.

In the first year we also included messages about SFUSD's Raising A Reader (RAR) program, which regularly sends books home to children. In particular, we coupled parent-child reading activities with texts about RAR to alleviate concerns that families without books could not engage in the suggested reading activities. For example:

TIP: Use the RAR red book bag to build your routine. Let your child hold the book. Ask what it is about. Follow the words with your finger as you read.

In the vast majority of cases, READY4K! texts build on activities that parents already do with their children. By extending pre-existing family routines, the program's messages minimize the costs of adopting beneficial home literacy practices. Parents do not have to take up new activities, which have time and emotional costs; they are simply asked to build on established routines. For example, the following "spiral" week of texts focuses on leveraging bath time: 
FACT: Bath time is great for teaching your child important skills $4 \mathrm{~K}$. Start by asking: What are the things we need for bath time? Why?

TIP: When you're bathing your child, point out the letters on shampoo bottles. Ask your child to name them and tell you the sounds that they make.

GROWTH: Keep using bath time to prepare your child 4K! Ask: What rhymes with tub (cub, rub), soap (rope, hope) and bubble (double, trouble)?

While parents in the treatment group received multiple READY4K! texts per week, parents in the control group received one placebo text about every two weeks. These messages pertained to the district's kindergarten enrollment requirements or required vaccinations. For example:

READY4K: Immunization forms are available at any San Francisco Health Center \& SFUSD's Educational Placement Center at 555 Franklin St., Room 100.

\section{3b. Study Participants}

We conducted the experimental study of READY4K! with parents of four-year-old preschoolers in SFUSD - administered by the Early Education Department (EED). EED serves roughly one-third of San Francisco's preschool market (the poorest third), operating 21 standalone sites and 13 sites that are co-located at elementary schools. Stand-alone and co-located sites function somewhat differently and have different sets of supports.

To recruit parents at stand-alone sites, we built on EED's existing enrollment processes by distributing READY4K! enrollment forms to the department's enrollment clerks and offering them ten dollars for each family that they enrolled. In SFUSD, parents of preschoolers must turn in a 
completed enrollment form to an enrollment clerk prior to the start of the school year. In the first year, to further encourage participation, we offered parents a ten-dollar Target gift card for enrolling in the program. We discontinued this incentive in the second year due to cost considerations, but this change did not pose a barrier to recruiting participants. In the first year, we also provided ten dollars per month or a 12 dollar monthly Amazon.com gift card to all participants because we did not want texting costs to represent a barrier to program participation. Surveys of parents in the first year indicated that most families have an unlimited texting plan. We therefore discontinued this incentive in the second year as well. This lack of incentive did not appreciably change attrition rates.

Unlike stand-alone sites, early education sites that are co-located at elementary schools do not have an EED enrollment clerk. In lieu of the above strategy we sent home information to eligible parents about the program along with our enrollment form. We also called some families and opted them into the study over the phone. The incentive structure in the first year was the same for these families.

We began program enrollment in early June and completed it in late September, about six weeks after the start of the school year, so as to include late preschool enrollees. Between the two years, 1,031 of 1,761 eligible families, representing all 34 sites enrolled in the study. ${ }^{4}$

Of the 1,031 families that enrolled in the study, 69 left SFUSD prior to the start of the school year and 27 left the district during the year, leaving an analytic sample of 935 families. Mobility is generally high in early education. Assuming that READY4K! did not affect initial

${ }^{4}$ In the first year, 519 of 874 families enrolled in the program and represented 31 of the 34 sites. In the second year of the program, 512 of 887 families enrolled in the program and represented all sites. 
enrollment or mid-year exit decisions, only 17 out of 935 families intentionally left the study - an opt-out rate of roughly two percent.

Table 1 presents descriptive statistics on the sample of families represented in the parent surveys, teacher surveys, and academic assessment. Sample sizes are smaller than the 935 families due to survey non-response and student absences during the assessment window. The teacher survey sample size is smaller because we were unable to survey teachers in the second year. While nearly all families in the district receive financial aid for preschool attendance costs (e.g., during the 2012-13 school year, only 12 percent of families paid full tuition), the participants in this study are diverse in other ways. As shown in Table 1, roughly 34 percent of children in the academic sample are Hispanic, 34 percent are Chinese, and 12 percent are black. The average fall age of children and parents in the sample is 4.40 and 34.61 years, respectively. About half of the parents, 51 percent, chose to receive texts in English, 24 percent chose Spanish, and 25 percent chose Chinese. Most parents (80 percent) had an unlimited texting plan at the start of the study. Demographically, the population of four year olds in SFUSD is similar in composition to the analytical sample. The population is 15 percent black, 35 percent Hispanic, 27 percent Chinese, and slightly older (4.48 years old).

Parents' baseline practices and children's baseline skills also vary. While on average, parents reported engaging in literacy-building activities with their child three to six times per week (including story-telling, reading, and singing), many parents reported engaging in this activities more or less often. Similarly, parents reported a high degree of variation in their children's pre-treatment early literacy skills. While on average, parents indicated that their children know most of the letters and can produce letter sounds and rhyme somewhat well, the variation around these averages is quite large. Children's direct assessment scores support 
parents' reports. For example, the average fall literacy assessment score of children in the academic sample is approximately 52 out of 126 , with a standard deviation of about 37 .

\section{3c. Data}

This study uses multiple sources of data describing four year olds in SFUSD and their parents. Information on parents comes from three sources: the READY4K! enrollment form, an end-of-year survey of parents, and an end-of-year survey of teachers (the teacher survey was only fielded in the first year). In the enrollment form, we collected basic information from parents including their home address, cell phone number, cell phone service provider, and if they have unlimited texting. We also asked parents to rate their early literacy-related parenting practices and their children's early literacy skills (Table 1 gives summary statistics). We collected these data prior to the start of the intervention and all parents partially or fully completed the form.

At the end of each respective school year, we mailed surveys to families' homes, in which we asked parents about their experiences participating in the study (we also sent a text message to parents with a link to an on-line version of the survey). We asked all parents about their experiences receiving and using study texts messages, as well as the activities they engaged in to help develop their children's early literacy skills. We offered parents 50 dollars for completing the survey. Ultimately $558 \mathrm{did}$ so, resulting in a response rate of approximately 60 percent.

In the first year of the experiment, we also surveyed teachers about parental involvement. We asked them about the frequency with which parents asked questions about their child's interests, what their child is doing and learning in school, and things they can do to help their child learn to read. Teachers did not know which parents were in the treatment group and which were in the control group. As with parents, we offered teachers 50 dollars for completing the survey. 
Overall, 63 teachers covering 258 of 449 families in the first year of the experiment completed and returned them - a response rate of about 57 percent.

To describe students, we use two additional sources of information: SFUSD's administrative records and students' spring scores on the district's early literacy assessment. In the spring of each school year, the district assesses the early literacy skills of four years olds using Phonological Awareness Literacy Screening (PALS). PALS was developed and validated at the University of Virginia (Invernizzi et al. 2004). PALS is a one-on-one assessment that takes about 20 to 30 minutes to complete. It includes tests of children's name writing skills, alphabet knowledge, beginning sound awareness, print and word awareness, rhyme awareness, and nursery rhyme awareness. The assessment has a leveled component: in the alphabet knowledge subtest, children who correctly identify 16 or more upper-case letters move on to be assessed in lower-case letters; and, children who correctly identify nine or more lower-case letters move on to letter sounds. SFUSD collects PALS data through a partnership with the University of San Francisco, which uses education graduate students to administer the assessment. The PALS assessment window was between March and April, well before the end of the READY4K! intervention, which occurred in May. All of the students in this study were assessed with the English-language version of PALS.

\section{3d. Randomization Checks}

In expectation, the only difference between the treatment group and the control group in a randomized experiment is treatment status. On average, all other characteristics of treatment and control group members, such as race, should be balanced. If by chance, despite the randomization process, there is imbalance across the groups, then treatment effect estimates could be biased. 
We randomized READY4K! within sites and therefore estimate a set of site fixed effects models to evaluate covariate balance. These models take the following form:

$$
X_{i s t}=\beta_{1} T_{i s t}+\gamma_{s t}+\varepsilon_{i s t}
$$

where $X_{\text {ist }}$ is a pre-treatment covariate of child $i$ (or his or her parent) in site $s$ in year $t, T_{\text {ist }}$ is the treatment status of the parent of child $i$ in site $s$ in year $t, \gamma_{s t}$ is a site-by-year fixed effect, and $\varepsilon_{i s t}$ is a child-level (or parent-level) error term (standard errors are clustered at the site-by-year level). We examine the balance of several pre-treatment covariates, including: child age, race, and gender; parents' ratings of children's pre-treatment early literacy skills; children's fall assessment scores; parents' age, texting language, and parents' self-reports of their early literacy-related parenting activities.

Table 2 illustrates that between the two years of the program there is little evidence of covariate imbalance. Of the 57 estimates we generate to assess imbalance, only five are statistically significant at the ten percent level or less (nine percent of the estimates). This estimated difference could occur by chance. Further, we cannot reject the null hypothesis that the covariates are jointly different from zero in the parent survey and academic samples, but can in the teacher sample. ${ }^{5}$ Appendix Table A3 shows that the first year of the program has more significant imbalance, while the second year of the program does not. In all cases we present results separately for each year, and combined between years, in models that include and exclude covariates.

\section{3e. Estimating Treatment Effects}

This study evaluates the impact of READY4K! on parents' attitudes towards the program, related texting behaviors, home literacy practices, and involvement at school, as well as children's

5 In robustness checks using robust standard error assumptions, we cannot reject the null hypothesis that the covariates are jointly different from zero in all three samples, including the teacher survey sample. Results available upon request. 
early literacy skills. To assess the effect of the program on parents, we start by examining the endof-year parent survey data. In the survey, we asked parents about their attitudes toward READY4K! and their program-related texting behaviors. In particular, we asked parents if they read and used READY4K! text messages and if they found the texts to be helpful. We also asked if they shared the texts and would recommend READY4K! to other parents.

To evaluate the effects of the program on parents' attitudes toward READY4K! and texting behaviors, we estimate two sets of models. In the first set of models we simply regress measures of parents' texting attitudes and behaviors on treatment status and site-by-year fixed effects to account for our randomization strategy. The second set of models adds all pre-treatment covariates to increase the precision of effect estimates and to account for any imbalance in the covariates. The second set of models takes the following form:

$$
Y_{i s t}=\beta_{1} T_{i s t}+X_{i s t} \beta_{2}+\gamma_{s t}+\varepsilon_{i s t}
$$

where $Y_{i s t}$ is a measure of the attitude of parent $i$ in site $s$ in year $t$ toward READY4K! or programrelated texting behavior, $T_{i s t}$ is the parent's treatment status, $\gamma_{s t}$ is a site-by-year fixed effect, $X_{i s t}$ is a vector of pre-treatment covariates, and $\varepsilon_{i s t}$ is a parent-level error term (standard errors are clustered at the site-by-year level). The vector of covariates, $X_{i s t}$, include all the variables in Table 2 including child gender, race, age, and performance on the baseline literacy assessment and parent gender, age, education, responses to baseline survey questions, and choice of texting language. In addition, we add an indicator if the child progressed to the leveled portion of the literacy exam in the fall. When running our models, we imputed missing values as 0 for indicator variables and the sample mean for continuous variables and included a missing indicator in the regression. For the performance on the fall literacy assessment we included indicators for missing any of the underlying questions that contribute to the total score. In all tables, "administrative and fall parent 
survey covariates" refer to all variables except the performance on the fall assessment. Those variables are referred to as "fall literacy assessment covariates."

In addition to asking about texting behaviors and attitudes, the end-of-year survey also asked parents about their home literacy activities. In particular, it asked them to indicate how many times during the last week they engaged in various activities, such as helping their children write their name, reciting nursery rhymes, and reading to their children. Our first step in analyzing this data is to conduct a factor analysis to help assess the dimensionality of the data. Results of this analysis indicate that one underlying early literacy parenting factor explains approximately 48 percent of the variance in the data in the first year and 58 percent in the second year. Based on this result, we use principal components analysis to create a global home literacy composite variable (see Appendix Table A6 for the elements of this composite and their weightings).

To evaluate the effects of READY4K! on parents' home literacy practices, we use the same two-model approach described above. We include as outcomes the global home literacy composite variable and specific home literacy practices, including how often parents read to their children, looked at pictures in a book, told stories, pointed out words that begin with the same sound and words that rhyme, showed their children the different parts of a book (e.g., cover, author, title, and pages), recited nursery rhymes, pointed out letters in the home environment, and said and explained new words using household objects. In the second year of the experiment we were able to ask only a subset of the questions we fielded in the first year. We therefore present results for each question fielded in each year, the home literacy composite variable from each year, and a pooled home literacy composite variable.

We also use the aforementioned two-model approach to evaluate the effects of the treatment on parental involvement at school and children's early literacy development. The 
outcomes for our analysis of parental involvement at school are teachers' end-of-year ratings of how often parents ask questions about their children, including questions about: their child's interests and friends; how their child gets along with others; what their child is doing and learning in school; their child's understanding of early literacy skills; things they can do at home to help their child learn to read; and children's book recommendations. As with the parental home literacy activity data, we use principal components analysis to create a global composite variable for parental involvement at school. We find that one factor explains about 81 percent of the variance in the school involvement data (see Appendix Table A6 for elements and their weightings).

To evaluate the effects of READY4K! on children's literacy development, we use children's spring PALS scores. We examine the impact of the program on both children's individual subtest scores and their average scores on PALS. To generate average scores, we standardized children's subtests scores, took an average of these standardized scores, and standardized the average. We chose this approach because not all students took all subtests and different subtests contain different numbers of items (our objective was to give equal weighting to each subtest). For example, the upper-case letter knowledge subtest has 26 items, whereas the maximum score on the name writing subtest is seven. Given that initial knowledge explains much of the variation in spring test scores, we include controls for children's baseline assessment scores in the fully-specified model, as described above.

\section{3f. Attrition Analysis}

Like many preschool programs, SFUSD's program experiences significant attrition. As noted above, 96 participating families left the district prior to or during the school year. Not including these families, 17 families opted out of the study. The children of 114 families were not tested in spring, in large part due to absences on testing day. As a result, we only have spring test 
score data on 821 children (89 percent of the 935 families who stayed in the district for the entire year). In total, 558 parents filled out the parent survey and 63 teachers provided information on the parental involvement of 258 parents (60 and 57 percent of staying families, respectively).

The biggest concern with study attrition pertains to bias. If the types of treatment group families who attrited are systematically different than the type of control group families who attrited in a way that is related to study outcomes, then results are likely biased. For example, if poorer families leave the treatment group at a higher rate than they leave the control group, and income is positively related to study outcomes, than results are likely biased upward.

We analyze attrition in the parent survey data, teacher survey data, and child outcome data by testing whether attrition differs by treatment status. In particular, we regress a binary variable that equals one if a family attrited on treatment status, controlling for site-by-year fixed effects. Table 3 does not show evidence of differential attrition between the treatment and control groups for any sample in either year. We test for differential attrition by treatment status and baseline covariate by estimating a series of models that take the following form:

$$
A_{i s t}=\beta_{1} T_{i s t}+\beta_{2} X_{i s t}+\beta_{3} T_{i s t} * X_{i s t}+\gamma_{s t}+\varepsilon_{i s t}
$$

where $A_{i s t}$ equals one if the family of child $i$ in site $s$ attrited in year $t$ from the sample, $T_{i s t}$ is the treatment status of the parent of child $i$ in site $s$ in year $t, X_{i s t}$ is a pre-treatment covariate of child $i$ or his or her parent, $T_{i s t} * X_{i s t}$ is an interaction of treatment status and the covariate, $\gamma_{s t}$ is a site-by-year fixed effect, and $\varepsilon_{i s t}$ is a child-level error term (standard errors are clustered at the site-by-year level). The coefficient on $\beta_{3}$ indicates whether or not there is differential attrition with respect to $X_{\text {ist }}$ across the treatment and control groups. Appendix Table A7 presents the results of this exercise for the pooled sample. Of the 57 tests, three are significant at the ten percent level or less, which could occur by chance. 


\section{Results}

\section{4a. Main Effects}

We find strong evidence that parents in the treatment group used READY4K! texts and found the program to be helpful. As Table 4 indicates, parents who received READY4K! texts were about 0.28 standard deviations (SD) more likely to use the information than parents who received placebo texts $(\mathrm{p}<0.05)$. Moreover, the difference in the extent to which treatment and control group parents found READY4K! texts to be helpful is roughly $0.41 \mathrm{SD}(\mathrm{p}<0.01)$. The effect of the program on the extent to which parents would recommend study texts is about 0.30 $\mathrm{SD}(\mathrm{p}<0.01)$. Parents in the treatment group were also more likely to share to READY4K! texts with other parents than control group parents - an effect of approximately $0.28 \mathrm{SD}(\mathrm{p}<0.05)$. If parents in the treatment group shared texts with parents in the control group, then study results are likely biased towards zero. However, we cannot test for this type of experimental contamination.

In addition to having positive attitudes toward READY4K! and program-related texting behaviors, we find evidence that the treatment group parents reported engaging in more home literacy activities with their children than parents in the control group. The results are particularly robust in the first year of the experiment. As illustrated in Table 5, in the first year of the experiment READY4K! positively affected the frequency with which parents reported telling stories, reciting nursery rhymes, looking at pictures in a book, and showing their children's different parts of a book, such as the title, author, and page number. The effects sizes range from approximately 0.19 SD to 0.29 SD and all results are significant at conventional levels (see Model 2). Similarly, READY4K! had a positive effect of about $0.27 \mathrm{SD}$ on the global early literacy parenting composite variable $(\mathrm{p}<0.05)$. In the second year of the experiment the point estimates are about half as large and insignificant. We discuss possible reasons for this discrepancy in Section 4d. Pooling between 
the two years indicates that parents engaged in home literacy activities to a greater extent by 0.156 $\mathrm{SD}(\mathrm{p}<0.10)$

We summarize the effects of READY4K! on parental involvement at school in Table 6. According to teachers, parents in the intervention group were significantly more likely to ask questions about their children. While not all of the differences in the individual variables are statistically significant, the frequency with which treatment group parents asked the teacher about their child's friends, how their children get along with others, what their children are doing in school, and things they can do to help their children learn to read is approximately 0.19 to $0.27 \mathrm{SD}$ greater than the frequency with which control group parents asked these questions $(\mathrm{p}<0.10$ to $\mathrm{p}<0.05)$. Likewise, READY4K! had a marginally significant positive effect of about $0.14 \mathrm{SD}$ on the parental involvement composite variable.

In Table 7, we summarize the effects of the intervention on children's early literacy assessment scores. We present results on the average score of all questions, knowing that some children did not progress to the leveled portion of the assessment and are therefore missing scores for lower case letter recognition and letter sound awareness (we did not impute zeroes for these children). We also present results on the average of the questions that were not part of the leveled portion of the exam and on each individual item. Panels A and B report those results for each experiment year. Panel $\mathrm{C}$ reports the results for individual items, pooled between experiment years.

Our findings indicate that the intervention had a number of positive effects on children's literacy development. Panel A illustrates that the first year of the experiment generated small, but insignificant positive estimates on the average of all questions, and no effects on the average of the non-leveled questions. In the second year, however, there is a robust $0.146 \mathrm{SD}(\mathrm{p}<0.05)$ increase in the average of all questions, and a marginally significant $0.122 \mathrm{SD}$ increase in the average of the 
non-leveled questions. Panel C illustrates that pooling years results in a $0.109 \mathrm{SD}(\mathrm{p}<0.05)$ increase in the average of all questions. Looking at the individual questions, the results appear to be driven by increases in lower case letter recognition and letter sounds awareness. The remainder of the individual questions have positive, but small and insignificant point estimates. The intervention also did not affect the propensity to move on to the leveled portion of the assessment. Given that children were assessed seven to 11 weeks prior to the end of the intervention (22 to 34 percent of the program remaining), it is possible to view this as a lower-bound estimate.

\section{4b. Heterogeneity Analysis}

The main results indicate that the program increased the literacy performance of children in the treatment group by $0.11 \mathrm{SD}$ to $0.15 \mathrm{SD}$. An open question is which part of the skills distribution these types of interventions help the most. On one hand, families of children who perform better at baseline may be more likely to interact with the texts to produce even greater learning gains for their children. If this were the case, the program may increase the inequality of outcomes in this population. Alternatively, children who are weaker at baseline stand to benefit the most from interacting with the activities because they have the most room to grow. In this scenario, the intervention could plausibly decrease the achievement gap of children in this population.

We explore which of these scenarios are at play by dividing the sample in half based on student performance at baseline. We identify the median student performance on the fall administration of PALS and separate those children who scored above and below the median. Table 8 presents the results for children scoring below the median of the baseline skill distributions and shows that the programmatic benefits are concentrated on this population of students. Model 2 indicates that the treatment increased the average performance of children by $0.33 \mathrm{SD}$ and $0.35 \mathrm{SD}$ 
$(\mathrm{p}<0.05)$ in the first and second year of the program, respectively. In the pooled sample, children benefited by $0.31 \mathrm{SD}(\mathrm{p}<0.01)$. Looking at the average of the non-leveled questions, power is limited in any one year, though the point estimates are consistently around $0.25 \mathrm{SD}$. In the pooled sample the children benefited by a significant $0.26 \mathrm{SD}(\mathrm{p}<0.05)$. The analysis of individual questions indicate that these benefits are found on several individual skills. Children benefited in identifying upper case letters, lower case letters, letter sounds, and in the ability to write their name. Point estimates range from 0.18SD to 0.53SD ( $<<0.10$ to $\mathrm{p}<0.05)$. Appendix Table A5 reports these results for children who scored above the median of the baseline skill distribution. Strikingly, all point estimates are insignificant and quantitatively small, with no consistent direction in point estimates. Overall, children weaker at baseline experienced the benefits of the program, indicating that the program may have reduced some achievement gaps. ${ }^{6}$ Notably, these results are consistent between years of the experiment. ${ }^{7}$

\section{4c. Differences in Outcomes Across Years}

Ex post, it is unclear why the estimated effects of the program were lower in the first year for the full sample, though very similar for those students starting off with weaker skills. We can

${ }^{6}$ Substantial heterogeneity can exist based on ethnicity of the participating families and by texting language. Small sample sizes hinder such an analysis, though there is suggestive evidence that results are larger for Hispanic families and for families that received texts in English or Spanish. These effects are once again concentrated on those children who scored below the median of the baseline PALS distribution.

${ }^{7}$ We have analyzed the robustness of the results to the Benjamini-Hochberg multiple corrections technique (1995). Effects of the program on parental attitudes towards the texts are robust to these corrections. Effects on parent activities, teacher reported outcomes, and overall PALS outcomes were not. Results on PALS outcomes for children below the median of baseline skills were either robust of very nearly so (p-value was within a few thousandths of the threshold). We consider the aggregate PALS outcomes outside the scope of the correction technique because it was a prespecified analysis. We take these results to mean that the texts were definitively well received by parents, that overall the program affected aggregate academic outcomes, and more robustly affected outcomes of students weaker at baseline. The remainder of the estimates provide some suggestive evidence on the mechanisms that could have produced these effects. 
only hypothesize why the point estimates differ. One possible explanation is simply that the program was new in the first year. Through an iterative process that included focus groups, we refined the texts, perhaps improving the quality of the texts. This improvement may be particularly strong for texts sent in Spanish and Chinese. Translating literacy tips into different languages poses a set of challenges. For example, the Chinese language does not have the concept of rhyming and English nursery rhymes do not translate into Spanish. As we continued to improve the program, we continued to ask native Spanish and Chinese to refine the translations to be culturally and linguistically relevant. ${ }^{8}$

A second possible reason for the stronger estimates in the second year is that a program that combines literacy, mathematics, and socio-emotional skills may be more effective than a pure literacy program. Parents may tire of engaging in only literacy skills over the course of eight months. Though each week brought with it an opportunity to engage in a new literacy skill, parents may benefit from more variety. An eight-month long texting program that asks parents to engage with their child in one domain may not be able to overcome limited attention in the longer term. In contrast, the combination program cycles among a literacy, mathematics, and socio-emotional skills thereby giving parents an opportunity to engage with their children in different ways each week. Practicing math and socio-emotional skills also may have spill over literacy benefits. Studies indicate that, at this age, the barriers between domains are not be rigid and that increasing the effect of one domain can improve performance on another (Butterworth 2005; Graziano et al. 2007;

\footnotetext{
${ }^{8}$ About half the participants in each year chose to receive texts in English, making the sample sizes in Chinese and Spanish small in any one given year. However, there is suggestive evidence that effect of the program increased for families receiving Spanish texts in the second year, while the program had little effect on families receiving Chinese texts in both years. This may indicate that texts improved over time in Spanish, but the linguistic barriers of the Chinese language remained in both years.
} 
Sarama et al. 2012; Morris et al. 2013). We are fielding more research to formally test whether these "combination" programs capture synergies between domains to amply results.

The larger estimates for the full sample in the second year of the program contrast with the point estimates on the survey results which are smaller in the second year. Again, we can only hypothesize, but the structure of the program may contribute to the differences in results between years. In the first year of the experiment, we provided parents two literacy tips a week for 8 months. In the second year of the program the literacy activities only comprised one third of the texts. Assuming that the take up of the program and habit formation was comparable between years, parents in the second year completed fewer literacy activities because they engaged in more mathematics and socio-emotional activities. In this regime, the texting program by definition would have a weaker effect on the frequency with which parents engaged in literacy activities. Positive spillovers to literacy from mathematics and socio-emotional activities may compensate for the reduced focus on literacy, resulting in stronger academic results in the second year.

\section{Discussion}

Young children with few learning opportunities at home exhibit fewer skills across a broad range of developmental domains - skills that are critical for economic success later in life (Heckman 2006). Traditional parenting information sessions often do little to ameliorate differences in children's at-home experiences. Interventions that target parents' literacy skills and in-home visitations show more promise; however, access to these programs is often low. Moreover, some parents who acquire the skills necessary to support their child's learning fail to stay involved in the long term, in part due to behavioral barriers.

This study examines the effectiveness of an early literacy text messaging program that targets the behavioral barriers to parental involvement by breaking down the complexity of 
parenting into bite-sized pieces and proving continuous encouragement and support over long periods of time. We find that the texting program approach positively affected parents and their children. Receiving READY4K! texts increased the extent to which parents engaged in home literacy activities with their children, with effect sizes ranging from about $0.16 \mathrm{SD}$ to $0.29 \mathrm{SD}$. The intervention also increased involvement at school, as reported by teachers, with effect sizes of 0.14 SD to $0.27 \mathrm{SD}$. Increases in parental activity and involvement led to learning gains among children, as READY4K! had an overall, significant positive effect of roughly 0.11 standard deviations on students' average spring PALS scores. The results, however, are concentrated on children who scored below the median of the baseline skills distribution. The 0.31 SD increase in scores among this group suggests that the program helps decrease achievement gaps among students.

Though the results of this study are promising we continue to field research investigating how to best structure these types of programs. For example, in a follow-up study, we (Doss et al. 2017) follow the sample of families in the first year of the program into kindergarten and recruit more of their kindergarten peers. We show that personalizing and differentiating the literacy tips can extract even larger academic gains. Children of parents who received the personalized and differentiated literacy tips were 63 percent more likely to be reading at a higher level in the fall of first grade when compared to the control group and a group that received a general text messaging program akin to the one in this study. This follow-up study indicates that these programs do more than merely hold the attention of parents and nudge them to engage with their children. Rather, the content is also critical, potentially providing information, reducing the cognitive load of parenting, holding attention, and addressing time-inconsistent preferences. The importance of content may explain why the results of the original study are concentrated in the children weaker at baseline. If the tasks were too easy for children scoring higher at baseline, they may not have had the 
opportunity to benefit from the program. Indeed, in the follow-up study there is evidence that the benefits of differentiation and personalization are particularly helpful for the stronger students who may not be well served by the general texts.

The importance of content raises further questions such as the effect of each component of the program (fact, tip, and growth) and whether all three features of the texting program have a larger effect than the sum of the components. That is, synergistic gains may be realized by targeting multiple behavioral barriers such as a lack of information, high cognitive load, lack of attention, and delayed gratification. We are currently fielding studies to probe these questions.

Interestingly, in the follow-up study, we find no significant effects in the general texting group in the full sample, which may raise questions regarding the consistency and replicability of the results. In probing this question more deeply we note that the follow-up study only contained the families of the first year of the original study, plus families recruited in kindergarten, and did not contain any recipients of the combined program. In this original study, the pure literacy program in the first year also produced weaker literacy outcomes, with significant results seen only for students below the median of the baseline skills distribution. With this fact in mind, we take the first-year participants of the original study and look at the effects of the follow-up intervention by the median of the baseline skills distribution (Table A8 presents the results). Strong inferences are difficult to make because the small sample of students is distributed among a control group and two treatment arms, and then divided in half. However, the point estimates are generally larger for the general text treatment for students below the median of the baseline skills distribution. The one exception being for the probability of exceeding expectations. Conversely, point estimates are generally larger and more positive for the personalized and differentiated text treatment for students above the median of the baselines skills distribution. No point estimate reaches the 
traditional level of significance and therefore the above analysis is only suggestive. The pattern of results, however, support the notion that the general text messages have a greater effect on weaker students at baseline, and the personalized and differentiated texts may help more advanced students at baseline. We, however, cannot preclude the possibility that the lack of strong results of general texts messages in the follow-up study is evidence that elements of the program did not replicate. In an effort to support replicability, the programs fielded in this study can be found in Appendices 3 and 4. Additionally, we are currently formally testing whether combining literacy, math, and socio-emotional domains into one program provides stronger results over programs that only support one domain. These studies will add further clarity regarding the nuances of the program and which conditions produce the strongest results.

Though more work needs to be done to fully understand these types of programs, this paper provides evidence that the READY4K! program meaningfully improved literacy outcomes for children entering preschool with weaker literacy skills. The estimated effects for this group are almost identical in the two years and two cohorts studied. A compelling implication of the findings is that text messaging and similar technologies that can provide small bits of information to a broad population could be viable strategies for promoting parental involvement and changing other complex adult behaviors. The vast majority of American adults have cell phones, nearly all cell phone owners already send and receive texts, and texting rates are particularly high in black and Hispanic populations. Moreover, virtually all text messages are opened (by comparison, the e-mail open rate in education is about 36 percent). We spent less than one dollar per family to send text messages per school year, and fixed program expenses such as content development costs trend towards zero on a per-family basis as the program scales. Scaling text messaging programs like READY4K! is easy, as adding users to the program requires little administrative work. Based on 
its widespread use, low cost, and scalability, text messaging is a potentially attractive alternative to other parenting interventions, which generally place significant demands on parents' time and effort and can be costly for providers, as well. 


\section{References}

Abraham, C. and Michie, S. (2008). A taxonomy of behavior change techniques used in interventions. Health Psychology, 27(3), pp. 379.

Anderson, M. (2015). Technology device ownership: 2015. Pew Research. Retrieved, December 15, 2015 from http://www.pewinternet.org/2015/10/29/technology-device ownership-2015

Astuto, J. and LaRue A. (2009). Home visitation and young children: An approach worth investing in? Society for Research in Child Development. Retrieved, December 15, 2015 from https://eric.ed.gov/?id=ED509749

Avery, C. and Kane, T.J. (2004). Student perceptions of college opportunities. The Boston COACH Program. In Caroline Hoxby (ed.) College choices: The economics of where to go, when to go, and how to pay for it, pp.355-394, Chicago: The University of Chicago Press.

Azzi-Lessing, L. (2011). Home visitation programs: Critical issues and future directions. Early Childhood Research Quarterly, 26(4), pp. 387-398.

Bandura, A. and Dale, S. (1981). Cultivating competence, self-efficacy, and intrinsic interest through proximal self-motivation. Journal of Personality and Social Psychology, 41(3), pp. 586-598.

Bergman, P. (2016). Parent-Child information frictions and human capital investment: Evidence from a field experiment. Working Paper. Retrieved April 8, 2016 from: http://www.columbia.edu/ psb2101/BergmanSubmission.pdf

Bettinger, E. P., Long, B.T., Oreopoulos, P., and Sanbonmatsu, L. (2012). The role of application assistance and information in college decisions: Results from the H\&R Block FAFSA experiment. The Quarterly Journal of Economics, 127(3), pp. 1205-1242.

Blom-Hoffman, J., O’Neil-Pirozzi, T., Volpe, R., Cutting, J., and Bissinger, E. (2007). Instructing parents to use dialogic reading strategies with preschool children: Impact of a video-based training program on caregiver reading behaviors and children's related verbalizations. Journal of Applied School Psychology, 23(1), pp. 117-131.

Bradley, R. H., Corwyn, R.F., Burchinal, M., McAdoo, H.P., and Coll, C.G. (2001). The home environments of children in the United States part II: Relations with behavioral development through age thirteen. Child Development, 72(6), pp. 1868-1886.

Bradley, R. H., Corwyn, R.F. McAdoo H.P., and Coll, C.G. (2001). The home environments of children in the United States part I: Variations by age, ethnicity, and poverty status. Child Development, 72(6), pp. 1844-1867.

Brotman, L. M., Calzada, E., Huang, K.Y., Kingston, S., Dawson-McClure, S., Kamboukos, D., 
Rosenfelt, A., Schwab, A., and Petkova, E. (2011). Promoting effective parenting practices and preventing child behavior problems in school among ethnically diverse families from underserved, urban communities. Child Development, 82(1), pp. 258-276.

Butterworth, B. (2005). The development of arithmetic abilities. Journal Child Psychology and Psychiatry, 46(1), pp. 3-18.

California Department of Education. (2008). California preschool learning foundations, volume 1. Sacramento, CA. Retrieved, December 15, 2015 from http://www.cde.ca.gov/sp/cd/re/ documents/preschoollf.pdf

Castleman, B. L. and Page L.C. (2015). Summer nudging: Can personalized text messages and peer mentor outreach increase college going among low-income high school graduates? Journal of Economic Behavior \& Organization, 115, pp. 144-160.

Costello, J.E., Compton, S.N., Keeler G., and Angold, A. (2003). Relationships between poverty and psychopathology: A natural experiment. Journal of the American Medical Association, 290(15), pp. 2023-2029.

Dahl, G. B. and Lochner, L. (2012). The impact of family income on child achievement: Evidence from the earned income tax credit. The American Economic Review, 102(5), pp. 19271956.

DellaVigna, S. (2009). Psychology and economics: Evidence from the field. Journal of Economic Literature, 47(2), pp. 315-372.

Doss, C., Fahle, M., Loeb, S., and York, B.N. (2017). Supporting parenting through differentiated and personalized text messaging: Testing effects on learning during kindergarten. CEPA Working Paper 16-18. Retrieved October 5, 2017 from https://cepa.stanford.edu/sites/default/files/wp16-18-v201611.pdf

Duncan, G. J., Ludwig, J., and Magnuson, K.A. (2010). Child development. In Phillip Levine and David Zimmerman (eds.) Targeting investments in children: Fighting poverty when resources are limited, pp. 27-58, Chicago: University of Chicago Press.

Ehrlich, S. (2013). Mogreet releases best practices guide for successfully navigating text marketing rules and regulations. The Wall Street Journal, February 17, 2013.

Golova, N., Alario A.J., Vivier, P.M., Rodriguez, M., and High, P.C. (1999). Literacy promotion for Hispanic families in a primary care setting: A randomized, controlled trial. Pediatrics, 103(5), pp. 993-997.

Graziano, P. A., Reavis, R.D., Keane, S.P., and Calkins, S.D. (2007). The role of emotion regulation in children's early academic success. Journal of School Psychology, 45(1), pp. 3-19. 
Grodsky, E. and Jones, MT. (2007). Real and imagined barriers to college entry: Perceptions of cost. Social Science Research, 36(2), pp. 745-766.

Hart, B., and Risley, T.R. (1995). Meaningful differences in the everyday experience of young American children, 1st ed. Baltimore, MD: Paul H. Brookes Publishing.

Hastings, J.S. and Weinstein, J.M. (2008). Information, school choice, and academic achievement: Evidence from two experiments. Quarterly Journal of Economics, 123(4), pp. 1373-1414.

Heckman, J.J. (2006). Skill formation and the economics of investing in disadvantaged children. Science, 312(5782), pp. 1900-1902.

Invernizzi, M., Sullivan A., Meier, J., and Swank, L. (2004). Phonological Awareness Literacy Screening (PALS) prek teacher's Manual. University of Virginia.

Iyengar, S., and Lepper, M. (2000). When choice is demotivating: Can one desire too much of a good thing? Personality \& Social Psychology, 79(6), pp. 995-1006.

Jordan, G.E., Snow C.E., and Porche, M.V. (2000). Project EASE: The effect of a family literacy project on kindergarten students' early literacy skills. Reading Research Quarterly, 35(4), pp. 524-546.

Karlan, D., McConnell, M., Mullainathan S., and Zinman J. (2016). Getting to the top of mind: How reminders increase saving. Management Science, 62(12), pp. 3393-3411.

Lonigan, C. J., and Shanahan, T. (2009). Developing early literacy: Report of the National Early Literacy Panel. National Institute for Literacy. Retrieved, December 15, 2005 from https://eric.ed.gov/?id=ED508381

Mani, A., Mullainathan, S., Shafir, E., and Zhao, J. (2013). Poverty Impedes Cognitive Function. Science, 341(6149), pp. 976-980.

Manz, P.H., Hughes C., Barnabas E., Bracaliello C., and Ginsburg-Block, M. (2010). A descriptive review and meta-analysis of family-based emergent literacy interventions: To what extent is the research applicable to low-income, ethnic-minority or linguistically-diverse young children? Early Childhood Research Quarterly, 25(4), pp. 409-431.

Mayer, S.E., Kalil, A., Oreopoulos, P., Gallegos, S. (2015). Using behavioral insights to increase parental engagement: The parents and children together (PACT) intervention. NBER Working Paper 21602. Retrieved October 5, 2017 from http://www.nber.org/papers/w7948

Melhuish, E. C., Phan, M.B., Sylva, K., Sammons, P., Siraj-Blatchford, I., and Taggart, B. (2008). Effects of the home learning environment and preschool center experience upon literacy and numeracy development in early primary school. Journal of Social Issues, 64(1), pp. 95-114. 
Mendelsohn, A.L., Mogilner L.N., Dreyer, B.P., Forman, J.A., Weinstein, S.C., Broderick, M., Cheng, K.J., Magloire T., Moore, T., and Napier, C. (2001). The impact of a clinic-based literacy intervention on language development in inner-city preschool children. Pediatrics, 107(1), pp. 130-134.

Morris, P., Millenky, M., Raver, C.C., and Jones, S.M. (2013). Does a preschool social and emotional learning intervention pay off for classroom instruction and children's behavior and academic skills? Evidence from the Foundations of Learning project. Early Education and Development, 24(7), pp. 1,020-1,042.

Mullainathan, S., and Thaler, R.H. (2000). Behavioral Economics. NBER Working Paper No. w7948. Retrieved December 15, 2015 from http://www.nber.org/papers/w7948

Needlman, R., Toker, K.H., Dreyer, B.P., Klass, P., and Mendelsohn, A.L. (2005). Effectiveness of a primary care intervention to support reading aloud: A multicenter evaluation. Ambulatory Pediatrics, 5(4), pp. 209-215.

NICHD Early Child Care Research Network. (2006). Child-care effect sizes for the NICHD study of early child care and youth development. The American Psychologist, 61, pp. 99.

Prinz, R.J., and Miller, G.E. (1994). Family-based treatment for childhood antisocial behavior: Experimental influences on dropout and engagement. Journal of Consulting and Clinical Psychology, 62(3), pp. 645-650.

Reese, E., Sparks, A., and Leyva, L. (2010). A review of parent interventions for preschool children's language and emergent literacy. Journal of Early Childhood Literacy, 10(1), pp. 97-117.

Riccio, J., Dechausay, N., Miller, C., Nuñez, S., Verma, N., and Yang, E. (2013). Conditional cash transfers in New York City: The continuing story of the Opportunity NYC-Family Rewards Demonstration. MDRC. Retrieved, December 15, 2015 from http://www.mdrc.org/ publication/conditional-cash-transfers-new-york-city

Sarama, J., Lange, A.A., Clements, D.H., and Wolfe, C.B. (2012). The impacts of an early mathematics curriculum on oral language and literacy. Early Childhood Research Quarterly, 27(3), pp. 489-502.

Sharif, I., Rieber, S., and Ozuah, P.O. (2002). Exposure to Reach Out and Read and vocabulary outcomes in inner city preschoolers. Journal of the National Medical Association, 94(3), pp. 171-177

Simon, H.A. (1955). A behavioral model of rational choice. The Quarterly Journal of Economics, 69(1), pp. 99-118.

Shah, A.K., Mullainathan S., and Shafir, E. (2012). The consequences of having too little. Science, 
338(6107), pp. 682-685.

Stevenson, H. W., Chen, C., and Uttal, D.H. (1990). Beliefs and achievement: A study of black, white, and Hispanic children. Child Development, 61(2), pp. 508-523.

Thaler, R.H., and Sunstein, C.R. (2009). Nudge: Improving decisions about health, wealth, and happiness, $2^{\text {nd }}$ ed. New Haven, CT: Yale Press.

United States Department of Health and Human Services. (1996). Physical activity and health: A report of the surgeon general. Retrieved, December 15, 2015 from https://www.cdc.gov/ nccdphp/sgr/

Valant, J., and Loeb, S. (2014). Information, choice, and decision-making: Field experiments with adult and student school choosers. Working Paper.

Whitehurst, G.J., Epstein, J.N., Angell, A.L., Payne, A.C., Crone, D.A., and Fischel, J.E. (1994). Outcomes of an emergent literacy intervention in Head Start. Journal of Educational Psychology, 86(4), pp. 542.

Zickuhr, K., and Smith, A. (2012). Digital differences. Pew Research Center. Retrieved, December 15, 2015 from http://www.english.illinois.edu/-people-/faculty/debaron/482/482readings/ PEW_Class.pdf

Zuckerman, B. (2009). Promoting early literacy in pediatric practice: Twenty years of Reach Out and Read. Pediatrics, 124(6), pp. 1660-166. 


\section{Appendix}

Table 1: Summary statistics (pooled sample)

\begin{tabular}{|c|c|c|c|c|c|c|}
\hline \multirow[b]{2}{*}{ Panel A. Children } & \multicolumn{2}{|c|}{$\begin{array}{l}\text { Parent Survey } \\
\text { Sample }\end{array}$} & \multicolumn{2}{|c|}{$\begin{array}{l}\text { Teacher Survey } \\
\text { Sample }\end{array}$} & \multicolumn{2}{|c|}{ Academic Sample } \\
\hline & Mean & (Std. Dev.) & Mean & (Std. Dev.) & Mean & (Std. Dev.) \\
\hline Female & 0.49 & - & 0.46 & - & 0.49 & - \\
\hline Hispanic & 0.28 & - & 0.41 & - & 0.34 & - \\
\hline Chinese & 0.35 & - & 0.26 & - & 0.34 & - \\
\hline Black & 0.13 & - & 0.12 & - & 0.12 & - \\
\hline White & 0.12 & - & 0.09 & - & 0.11 & - \\
\hline Other Race & 0.09 & & 0.12 & - & 0.09 & - \\
\hline Age in years (fall) & 4.39 & $(0.28)$ & 4.34 & $(0.29)$ & 4.40 & $(0.45)$ \\
\hline Parent rating of letter knowledge (fall) & 2.92 & $(0.91)$ & 2.84 & $(0.93)$ & 2.85 & $(0.94)$ \\
\hline $\begin{array}{l}\text { Parent rating of how often child ask to } \\
\text { be read to per week (fall) }\end{array}$ & 3.01 & $(0.88)$ & 2.94 & $(0.88)$ & 2.93 & $(0.91)$ \\
\hline $\begin{array}{l}\text { Child literacy assessment sum score } \\
\quad(\text { fall; } \max =126.0)\end{array}$ & 53.24 & $(37.27)$ & 48.67 & $(37.12)$ & 52.13 & $(36.79)$ \\
\hline \multicolumn{7}{|l|}{ Panel B. Parents } \\
\hline Female & 0.86 & - & 0.87 & - & 0.83 & - \\
\hline Age in years (fall) & 34.8 & $(6.03)$ & 34.1 & $(5.78)$ & 34.61 & $(6.47)$ \\
\hline Has less than a bachelor's degree & 0.72 & - & 0.73 & - & 0.74 & - \\
\hline Received texts in English & 0.55 & - & 0.48 & - & 0.51 & - \\
\hline Received texts in Spanish & 0.18 & - & 0.31 & - & 0.24 & - \\
\hline Received texts in Chinese & 0.27 & - & 0.21 & - & 0.25 & - \\
\hline $\begin{array}{l}\text { How many times per week parent } \\
\text { reads for pleasure (fall) }\end{array}$ & 2.57 & $(0.90)$ & 2.55 & $(0.87)$ & 2.56 & $(0.91)$ \\
\hline $\begin{array}{l}\text { How many times per week parent tells } \\
\text { a story to child (fall) }\end{array}$ & 2.87 & $(0.86)$ & 2.84 & $(0.84)$ & 2.82 & $(0.86)$ \\
\hline $\begin{array}{l}\text { How many times per week parent } \\
\text { sings to child (fall) }\end{array}$ & 3.07 & $(0.84)$ & 2.97 & $(0.82)$ & 3.05 & $(0.86)$ \\
\hline $\mathrm{N}=$ & 558 & & 258 & & 821 & \\
\hline
\end{tabular}

Notes. Parents rated the letter knowledge of their child in one of four categories: 1=The child knows no letters, 2=Some, $3=$ Most, 4=All. Answer options for weekly parental activities and how often the child asked to be read to include: $1=$ Not at all, 2=Once or twice per week, $3=$ Three to six times, $4=$ Every day. Missing values set at the sample average. 
Table 2: Randomization checks: The effect of treatment status on pre-treatment child covariates (pooled sample)

\begin{tabular}{|c|c|c|c|}
\hline Pre-treatment child covariates & $\begin{array}{c}\text { Parent Survey } \\
\text { Sample }\end{array}$ & $\begin{array}{c}\text { Teacher Survey } \\
\text { Sample }\end{array}$ & $\begin{array}{c}\text { Academic } \\
\text { Sample }\end{array}$ \\
\hline Child female & $\begin{array}{c}0.029 \\
(0.043)\end{array}$ & $\begin{array}{c}-0.05 \\
(0.063)\end{array}$ & $\begin{array}{l}-0.003 \\
(0.035)\end{array}$ \\
\hline Hispanic & $\begin{array}{l}-0.011 \\
(0.035)\end{array}$ & $\begin{array}{l}-0.059 \\
(0.045)\end{array}$ & $\begin{array}{l}-0.025 \\
(0.024)\end{array}$ \\
\hline Chinese & $\begin{array}{c}0.013 \\
(0.025)\end{array}$ & $\begin{array}{c}0.034 \\
(0.033)\end{array}$ & $\begin{array}{l}-0.002 \\
(0.020)\end{array}$ \\
\hline Black & $\begin{array}{c}0.017 \\
(0.024)\end{array}$ & $\begin{array}{c}0.031 \\
(0.044)\end{array}$ & $\begin{array}{l}0.033+ \\
(0.019)\end{array}$ \\
\hline White & $\begin{array}{l}-0.037 \\
(0.026)\end{array}$ & $\begin{array}{l}-0.015 \\
(0.027)\end{array}$ & $\begin{array}{l}-0.013 \\
(0.016)\end{array}$ \\
\hline Other Race & $\begin{array}{c}0.011 \\
(0.025)\end{array}$ & $\begin{array}{c}0.009 \\
(0.032)\end{array}$ & $\begin{array}{c}0.008 \\
(0.021)\end{array}$ \\
\hline Child age in years & $\begin{array}{c}0.023 \\
(0.028)\end{array}$ & $\begin{array}{c}0.02 \\
(0.042)\end{array}$ & $\begin{array}{c}0.052 \\
(0.037)\end{array}$ \\
\hline Parent female & $\begin{array}{l}-0.025 \\
(0.031)\end{array}$ & $\begin{array}{l}0.033 \\
(0.037)\end{array}$ & $\begin{array}{c}0.001 \\
(0.026)\end{array}$ \\
\hline Parent age in years & $\begin{array}{l}-0.023 \\
(0.639)\end{array}$ & $\begin{array}{l}-1.284+ \\
(0.643)\end{array}$ & $\begin{array}{c}0.529 \\
(0.504)\end{array}$ \\
\hline Less than bachelor's degree & $\begin{array}{l}-0.034 \\
(0.032)\end{array}$ & $\begin{array}{c}0.012 \\
(0.043)\end{array}$ & $\begin{array}{l}-0.017 \\
(0.026)\end{array}$ \\
\hline Parent rating of letter knowledge (fall) & $\begin{array}{l}0.166^{*} \\
(0.079)\end{array}$ & $\begin{array}{c}0.067 \\
(0.113)\end{array}$ & $\begin{array}{c}0.017 \\
(0.066)\end{array}$ \\
\hline How often child asks to be read to per week (fall) & $\begin{array}{l}-0.181+ \\
(0.096)\end{array}$ & $\begin{array}{l}-0.137 \\
(0.125)\end{array}$ & $\begin{array}{l}-0.134+ \\
(0.069)\end{array}$ \\
\hline How many times per week parent reads for pleasure (fall) & $\begin{array}{c}-0.007 \\
(0.081)\end{array}$ & $\begin{array}{c}0.129 \\
(0.088)\end{array}$ & $\begin{array}{l}-0.024 \\
(0.057)\end{array}$ \\
\hline How many times per week parent tells a story to child (fall) & $\begin{array}{l}-0.043 \\
(0.090)\end{array}$ & $\begin{array}{l}-0.035 \\
(0.123)\end{array}$ & $\begin{array}{l}0.011 \\
(0.068)\end{array}$ \\
\hline How many times per week parent sings to child (fall) & $\begin{array}{l}-0.007 \\
(0.086)\end{array}$ & $\begin{array}{c}0.005 \\
(0.137)\end{array}$ & $\begin{array}{l}-0.016 \\
(0.062)\end{array}$ \\
\hline Child literacy assessment sum score (fall; $\max =126.0$ ) & $\begin{array}{c}3.022 \\
(3.182)\end{array}$ & $\begin{array}{l}-5.071 \\
(4.322)\end{array}$ & $\begin{array}{l}-1.502 \\
(2.306)\end{array}$ \\
\hline Received texts in English & $\begin{array}{l}-0.032 \\
(0.031)\end{array}$ & $\begin{array}{c}0.017 \\
(0.040)\end{array}$ & $\begin{array}{c}0.025 \\
(0.029)\end{array}$ \\
\hline Received texts in Spanish & $\begin{array}{c}0.012 \\
(0.023)\end{array}$ & $\begin{array}{l}-0.043 \\
(0.026)\end{array}$ & $\begin{array}{l}-0.015 \\
(0.022)\end{array}$ \\
\hline Received texts in Chinese & $\begin{array}{c}0.02 \\
(0.025)\end{array}$ & $\begin{array}{c}0.026 \\
(0.032)\end{array}$ & $\begin{array}{l}-0.01 \\
(0.019)\end{array}$ \\
\hline p-value of test of joint significance & 0.410 & 0.016 & 0.320 \\
\hline$N=$ & 544 & 251 & 805 \\
\hline Randomization site-by-year fixed effects & $\checkmark$ & $\checkmark$ & $\checkmark$ \\
\hline
\end{tabular}

Notes. Fall parent survey responses are standardized. Standard errors are clustered at the randomization site-byyear level. Sample size varies by covariate due to missing data. The sample size indicated in the table is the average number of observations across covariates. The maximum sample size for the parent, teacher, and academic samples are 555, 258, and 821 respectively. + indicates $\mathrm{p}<0.10,{ }^{*} \mathrm{p}<0.05,{ }^{* *} \mathrm{p}<0.01$. 
Table 3: The effects of treatment status on study attrition

\begin{tabular}{|c|c|c|c|}
\hline & Year 1 & Year 2 & Pooled \\
\hline Academic Sample & $\begin{array}{c}0.003 \\
(0.045)\end{array}$ & $\begin{array}{c}0.018 \\
(0.037)\end{array}$ & $\begin{array}{c}0.011 \\
(0.029)\end{array}$ \\
\hline Parent Survey Sample & $\begin{array}{c}0.046 \\
(0.051)\end{array}$ & $\begin{array}{c}0.035 \\
(0.053)\end{array}$ & $\begin{array}{c}0.04 \\
(0.037)\end{array}$ \\
\hline Teacher Survey Sample & $\begin{array}{c}0.008 \\
(0.035)\end{array}$ & - & - \\
\hline $\mathrm{N}=$ & 519 & 512 & 1,031 \\
\hline Randomization site fixed effects & $\checkmark$ & $\checkmark$ & $\checkmark$ \\
\hline
\end{tabular}


Table 4: The effects of READY4K! on parents' text messaging behaviors and attitudes (pooled sample)

\begin{tabular}{lccc}
\hline \hline Texting behaviors and attitudes: & Model 1 & Model 2 & $\mathrm{N}$ \\
\hline Parent read text messages & 0.150 & 0.153 & 545 \\
& $(0.098)$ & $(0.106)$ & \\
Parent used text messages & $0.295^{* *}$ & $0.277^{*}$ & 545 \\
& $(0.103)$ & $(0.106)$ & \\
Parent found text messages helpful & $0.403^{* *}$ & $0.405^{* *}$ & 541 \\
& $(0.100)$ & $(0.098)$ & \\
Parent shared texts with other parents & $0.248^{*}$ & $0.277^{*}$ & 281 \\
& $(0.113)$ & $(0.135)$ & \\
Parent would recommend texts & $0.302^{* *}$ & $0.300^{* *}$ & 545 \\
& $(0.090)$ & $(0.088)$ & \\
Randomization site-by-year fixed effects & $\checkmark$ & $\checkmark$ & \\
Administrative and fall parent survey covariates & & $\checkmark$ & \\
Fall literacy assessment covariates & & $\checkmark$ & \\
\hline \hline
\end{tabular}

Notes. Reponses are pooled between experiment years, except for "Parents shared texts with other parents," which was only asked in the first year. All outcomes are standardized by year. Administrative and fall parent survey covariates include child gender, race, age, and parent gender, age, education, responses to baseline survey questions, and choice of texting language. Fall literacy assessment covariates are the total score on the fall literacy assessment and an indicator for advancing to the leveled portion of the exam. All missing indicator variables are imputed with a zero and continuous variables with the sample mean. Indicators for missing values are included. For the fall literacy assessment, indicators for missing any underlying questions are included. Standard errors are clustered at the randomization site-by-year level. + indicates $\mathrm{p}<0.10,{ }^{*} \mathrm{p}<0.05, * * \mathrm{p}<0.01$. 
Table 5: The effects of READY4K! on parents' home literacy activities

\begin{tabular}{|c|c|c|c|}
\hline Panel A. Home literacy activity composite variable & Model 1 & Model 2 & $\mathrm{~N}$ \\
\hline Global home literacy composite variable, experiment year 1 & $\begin{array}{c}0.149 \\
(0.111)\end{array}$ & $\begin{array}{l}0.269^{*} \\
(0.110)\end{array}$ & 267 \\
\hline Global home literacy composite variable, experiment year 2 & $\begin{array}{c}0.123 \\
(0.176)\end{array}$ & $\begin{array}{c}0.114 \\
(0.147)\end{array}$ & 269 \\
\hline Global home literacy composite variable, pooled sample & $\begin{array}{c}0.136 \\
(0.103)\end{array}$ & $\begin{array}{l}0.156+ \\
(0.090)\end{array}$ & 536 \\
\hline \multicolumn{4}{|l|}{ Panel B. Specific home literacy activities, experiment year 1} \\
\hline Pointed out letters in the home environment & $\begin{array}{l}-0.091 \\
(0.124)\end{array}$ & $\begin{array}{l}-0.034 \\
(0.115)\end{array}$ & 285 \\
\hline Pointed out two words that begin with the same sound to your child & $\begin{array}{c}0.141 \\
(0.129)\end{array}$ & $\begin{array}{c}0.186 \\
(0.112)\end{array}$ & 285 \\
\hline Pointed out two words that rhyme to your child & $\begin{array}{c}0.158 \\
(0.119)\end{array}$ & $\begin{array}{c}0.183 \\
(0.124)\end{array}$ & 282 \\
\hline Said \& explained a new word to your child using household objects & $\begin{array}{c}0.121 \\
(0.106)\end{array}$ & $\begin{array}{c}0.138 \\
(0.119)\end{array}$ & 287 \\
\hline Showed your child the different parts of a book (e.g., cover, title, author) & $\begin{array}{l}0.165+ \\
(0.082)\end{array}$ & $\begin{array}{l}0.228^{*} \\
(0.106)\end{array}$ & 285 \\
\hline Looked at pictures in a book with your child & $\begin{array}{l}0.240^{*} \\
(0.115)\end{array}$ & $\begin{array}{l}0.298^{*} \\
(0.126)\end{array}$ & 284 \\
\hline Showed or helped your child write his/her name & $\begin{array}{l}-0.002 \\
(0.117)\end{array}$ & $\begin{array}{c}0.071 \\
(0.131)\end{array}$ & 281 \\
\hline Read to your child & $\begin{array}{l}-0.022 \\
(0.115)\end{array}$ & $\begin{array}{c}0.081 \\
(0.121)\end{array}$ & 285 \\
\hline Told your child a story & $\begin{array}{c}0.100 \\
(0.101)\end{array}$ & $\begin{array}{l}0.191+ \\
(0.110)\end{array}$ & 287 \\
\hline Recited a nursery rhyme to your child & $\begin{array}{c}0.174 \\
(0.116)\end{array}$ & $\begin{array}{l}0.297 * \\
(0.117)\end{array}$ & 285 \\
\hline \multicolumn{4}{|l|}{ Panel C. Specific home literacy activities, experiment year 2} \\
\hline Pointed out letters to your child & $\begin{array}{c}0.042 \\
(0.144)\end{array}$ & $\begin{array}{c}0.049 \\
(0.130)\end{array}$ & 271 \\
\hline Practiced word sounds with your child & $\begin{array}{c}0.094 \\
(0.190)\end{array}$ & $\begin{array}{c}0.077 \\
(0.162)\end{array}$ & 271 \\
\hline Practiced rhyming with your child & $\begin{array}{c}0.112 \\
(0.158)\end{array}$ & $\begin{array}{c}0.126 \\
(0.143)\end{array}$ & 270 \\
\hline Helped your child learn new words & $\begin{array}{l}-0.046 \\
(0.178)\end{array}$ & $\begin{array}{l}-0.057 \\
(0.151)\end{array}$ & 271 \\
\hline Showed your child the different parts of a book (e.g., cover, title, author) & $\begin{array}{c}0.054 \\
(0.141)\end{array}$ & $\begin{array}{c}0.052 \\
(0.131)\end{array}$ & 270 \\
\hline Showed your child we read from left to right & $\begin{array}{c}0.165 \\
(0.173)\end{array}$ & $\begin{array}{c}0.150 \\
(0.147)\end{array}$ & 270 \\
\hline Worked on literacy skills during family activities (meals, kitchen, etc...) & $\begin{array}{c}0.178 \\
(0.126)\end{array}$ & $\begin{array}{c}0.169 \\
(0.123)\end{array}$ & 270 \\
\hline Randomization site-by-year fixed effects & $\checkmark$ & $\checkmark$ & \\
\hline Administrative and fall parent survey covariates & & $\checkmark$ & \\
\hline Fall literacy assessment covariates & & $\checkmark$ & \\
\hline
\end{tabular}

Notes. All outcomes are standardized by year. Standard errors are clustered at the randomization site-by-year level. Included covariates are detailed in Table $4 .+$ indicates $\mathrm{p}<0.10,{ }^{*} \mathrm{p}<0.05,{ }^{*} \mathrm{p}<0.01$. 
Table 6: The effects of READY4K! on parental involvement at school (experiment year 1)

\begin{tabular}{lccc}
\hline \hline Panel A. Parental involvement composite variable & Model 1 & Model 2 & N \\
\hline Global parental involvement composite variable & 0.117 & $0.138+$ & \multirow{2}{*}{$(0.078)$} \\
& $(0.075)$ & \\
Panel B. Teacher reports of how often parents ask questions about the following topics & \\
\hline Their child's interests & 0.047 & 0.105 & \multirow{2}{*}{254} \\
Their child's friends & $(0.079)$ & $(0.074)$ & \\
& 0.108 & $0.144+$ & 253 \\
How the child gets along with others & $(0.087)$ & $(0.082)$ & \\
& $0.221^{*}$ & $0.207^{*}$ & 254 \\
What their child is doing in school & $(0.093)$ & $(0.090)$ & \\
& $0.170+$ & $0.177+$ & 253 \\
What their child is learning in school & $(0.086)$ & $(0.086)$ & \\
& 0.078 & 0.076 & 254 \\
Their child's understanding of early literacy skills like the ABCs & $(0.089)$ & $(0.096)$ & \\
& $(0.101)$ & $(0.107)$ & 253 \\
Things they can do to help their child learn to read & $0.126+$ & $0.152^{*}$ & \multirow{2}{*}{254} \\
& $(0.068)$ & $(0.073)$ & \\
Book recommendations & 0.057 & 0.085 & 250 \\
& $(0.077)$ & $(0.074)$ & \\
Randomization site-by-year fixed effects & & & \\
Administrative and fall parent survey covariates & $\checkmark$ & $\checkmark$ & \\
Fall literacy assessment covariates & & $\checkmark$ & \\
\hline \hline
\end{tabular}

Notes. All outcomes are standardized. Standard errors are clustered at the randomization site-byyear level. Included covariates are detailed in Table 4. + indicates $\mathrm{p}<0.10,{ }^{*} \mathrm{p}<0.05,{ }^{*} \mathrm{p}<0.01$. 
Table 7: The effects of READY4K! On children's spring early literacy assessment scores

\begin{tabular}{lccc}
\hline \hline Panel A. Average outcomes, first year of experiment & Model 1 & Model 2 & $\mathrm{N}$ \\
\hline Average of all questions & 0.055 & 0.060 & 395 \\
Average of non-leveled questions & $(0.097)$ & $(0.082)$ & \\
& -0.014 & -0.015 & 395 \\
Panel B. Average outcomes, second year of experiment & $(0.093)$ & $(0.082)$ & \\
\hline Average of all questions & $0.142+$ & $0.146^{*}$ & \multirow{2}{*}{426} \\
Average of non-leveled questions & $(0.076)$ & $(0.068)$ & \\
& 0.117 & $0.122+$ & 426 \\
Panel C. All outcomes, pooled sample & $(0.072)$ & $(0.072)$ & \\
\hline Average of all questions & & & \\
& 0.100 & $0.109^{*}$ & \multirow{2}{*}{821} \\
Average of non-leveled questions & $(0.061)$ & $(0.054)$ & \\
& 0.054 & 0.062 & 821 \\
Upper case letter recognition & $(0.059)$ & $(0.057)$ & \\
& 0.041 & 0.039 & 814 \\
Beginning word sound awareness & $(0.065)$ & $(0.049)$ & \multirow{2}{*}{0.012} \\
Print and word awareness & -0.007 & 0.012 & 796 \\
& $(0.074)$ & $(0.072)$ & \\
Rhyme awareness & 0.064 & 0.054 & 801 \\
Name writing & $(0.064)$ & $(0.068)$ & \\
& 0.016 & 0.019 & 784 \\
Probability of progressing to leveled portion of assessment & $(0.069)$ & $(0.063)$ & \\
& 0.047 & 0.041 & 817 \\
Lower case letter recognition & $(0.064)$ & $(0.069)$ & \\
Letter sounds awareness & $(0.015$ & -0.004 & 821 \\
Randomization site-by-year fixed effects & $(0.026)$ & \\
Administrative and fall parent survey covariates & 0.089 & $0.124+$ & 594 \\
Fall literacy assessment covariates & $(0.087)$ & $(0.068)$ & \multirow{2}{*}{558} \\
\hline \hline
\end{tabular}

Notes. All outcomes are standardized by year. Standard errors are clustered at the randomization siteby-year level. Included covariates are detailed in Table $4 .+$ indicates $\mathrm{p}<0.10,{ }^{*} \mathrm{p}<0.05,{ }^{* *} \mathrm{p}<0.01$. 
Table 8: Heterogeneity in READY4K! effects on children's spring early literacy assessment scores Sample of children below median of baseline skills

\begin{tabular}{lccc}
\hline \hline Panel A. Average outcomes, first year of experiment & Model 1 & Model 2 & $\mathrm{~N}$ \\
\hline Average of all questions & 0.193 & $0.330^{*}$ & \multirow{2}{*}{198} \\
& $(0.155)$ & $(0.137)$ & \\
Average of non-leveled questions & 0.128 & $0.253+$ & 198 \\
& $(0.154)$ & $(0.145)$ & \\
Panel B. Average outcomes, second year of experiment & & & \\
\hline Average of all questions & $0.306^{*}$ & $0.348+$ & \multirow{2}{*}{207} \\
& $(0.132)$ & $(0.180)$ & \\
Average of non-leveled questions & $0.250+$ & 0.286 & 207 \\
Panel C. All outcomes, pooled sample & $(0.135)$ & $(0.183)$ & \\
\hline Average of all questions & & & \\
& $0.253^{*}$ & $0.313^{* *}$ & \multirow{2}{*}{406} \\
Average of non-leveled questions & $(0.101)$ & $(0.108)$ & \\
Upper case letter recognition & $0.192+$ & $0.261^{*}$ & 405 \\
& $(0.102)$ & $(0.112)$ & \\
Beginning word sound awareness & 0.123 & $0.175+$ & 400 \\
Print and word awareness & $(0.101)$ & $(0.101)$ & \\
Rhyme awareness & -0.051 & 0.014 & 388 \\
Name writing & $(0.137)$ & $(0.126)$ & \\
Probability of progressing to leveled portion of assessment & 0.179 & 0.179 & 391 \\
Lower case letter recognition & $(0.110)$ & $(0.118)$ & \\
Letter sounds awareness & 0.11 & 0.118 & 378 \\
Randomization site-by-year fixed effects & $(0.107)$ & $(0.117)$ & \\
Administrative and fall parent survey covariates & 0.218 & $0.287+$ & 402 \\
Fall literacy assessment covariates & $(0.147)$ & $(0.156)$ & \\
\hline \hline
\end{tabular}

Notes. All outcomes are standardized by year. Standard errors are clustered at the randomization site-by-year level. Included covariates are detailed in Table $4 .+$ indicates $\mathrm{p}<0.10,{ }^{*} \mathrm{p}<0.05,{ }^{* *} \mathrm{p}<0.01$. 
Table A1: Summary statistics (Experiment Year 1)

\begin{tabular}{|c|c|c|c|c|}
\hline \multirow[b]{2}{*}{ Panel A. Children } & \multicolumn{2}{|c|}{$\begin{array}{c}\text { Parent Survey } \\
\text { Sample }\end{array}$} & \multicolumn{2}{|c|}{ Academic Sample } \\
\hline & Mean & (Std. Dev.) & Mean & (Std. Dev.) \\
\hline Female & 0.48 & - & 0.47 & - \\
\hline Hispanic & 0.29 & - & 0.33 & - \\
\hline Chinese & 0.31 & - & 0.32 & - \\
\hline Black & 0.17 & - & 0.13 & - \\
\hline White & 0.11 & - & 0.1 & - \\
\hline Other Race & 0.11 & - & 0.12 & - \\
\hline Age in years (fall) & 4.33 & $(0.29)$ & 4.33 & $(0.29)$ \\
\hline Parent rating of letter knowledge (fall) & 2.91 & $(0.90)$ & 2.89 & $(0.94)$ \\
\hline Parent rating of how often child ask to be read to per week (fall) & 2.97 & $(0.87)$ & 2.95 & $(0.89)$ \\
\hline Child literacy assessment sum score (fall; $\max =126.0$ ) & 54.22 & $(37.53)$ & 53.35 & $(37.54)$ \\
\hline \multicolumn{5}{|l|}{ Panel B. Parents } \\
\hline Female & 0.87 & - & 0.85 & - \\
\hline Age in years (fall) & 34.42 & $(5.42)$ & 34.34 & $(5.58)$ \\
\hline Has less than a bachelor's degree & 0.7 & - & 0.72 & - \\
\hline Received texts in English & 0.58 & - & 0.51 & - \\
\hline Received texts in Spanish & 0.2 & - & 0.25 & - \\
\hline Received texts in Chinese & 0.22 & - & 0.24 & - \\
\hline How many times per week parent reads for pleasure (fall) & 2.57 & $(0.88)$ & 2.55 & $(0.87)$ \\
\hline How many times per week parent tells a story to child (fall) & 2.86 & $(0.85)$ & 2.85 & $(0.85)$ \\
\hline How many times per week parent sings to child (fall) & 2.92 & $(0.83)$ & 2.90 & $(0.84)$ \\
\hline $\mathrm{N}=$ & 287 & & 395 & \\
\hline
\end{tabular}

Notes. Parents rated the letter knowledge of their child in one of four categories: $1=$ The child knows no letters, 2=Some, 3=Most, 4=All. Answer options for weekly parental activities and how often the child asked to be read to include: $1=$ Not at all, $2=$ Once or twice per week, $3=$ Three to six times, $4=$ Every day. Missing values set at the sample average. 
Table A2: Summary statistics (Experiment Year 2)

\begin{tabular}{|c|c|c|c|c|}
\hline \multirow[b]{2}{*}{ Panel A. Children } & \multicolumn{2}{|c|}{$\begin{array}{c}\text { Parent Survey } \\
\text { Sample } \\
\end{array}$} & \multicolumn{2}{|c|}{ Academic Sample } \\
\hline & Mean & (Std. Dev.) & Mean & (Std. Dev.) \\
\hline Female & 0.50 & - & 0.50 & - \\
\hline Hispanic & 0.28 & - & 0.35 & - \\
\hline Chinese & 0.39 & - & 0.36 & - \\
\hline Black & 0.09 & - & 0.11 & - \\
\hline White & 0.12 & - & 0.11 & - \\
\hline Other Race & 0.06 & - & 0.07 & - \\
\hline Age in years (fall) & 4.45 & $(0.25)$ & 4.47 & $(0.55)$ \\
\hline Parent rating of letter knowledge (fall) & 2.94 & $(0.93)$ & 2.8 & $(0.94)$ \\
\hline Parent rating of how often child ask to be read to per week (fall) & 3.06 & $(0.88)$ & 2.91 & $(0.94)$ \\
\hline Child literacy assessment sum score (fall; $\max =126.0$ ) & 52.23 & $(37.04)$ & 51.00 & $(36.09)$ \\
\hline \multicolumn{5}{|l|}{ Panel B. Parents } \\
\hline Female & 0.85 & - & 0.81 & - \\
\hline Age in years (fall) & 35.19 & $(6.59)$ & 34.86 & $(7.19)$ \\
\hline Has less than a bachelor's degree & 0.75 & - & 0.77 & - \\
\hline Received texts in English & 0.52 & - & 0.51 & - \\
\hline Received texts in Spanish & 0.17 & - & 0.22 & - \\
\hline Received texts in Chinese & 0.32 & - & 0.27 & - \\
\hline How many times per week parent reads for pleasure (fall) & 2.58 & $(0.93)$ & 2.57 & $(0.95)$ \\
\hline How many times per week parent tells a story to child (fall) & 2.88 & $(0.87)$ & 2.79 & $(0.88)$ \\
\hline How many times per week parent sings to child (fall) & 3.23 & $(0.83)$ & 3.18 & $(0.86)$ \\
\hline $\mathrm{N}=$ & 271 & & 426 & \\
\hline
\end{tabular}

Notes. Parents rated the letter knowledge of their child in one of four categories: $1=$ The child knows no letters, 2=Some, 3=Most, 4=All. Answer options for weekly parental activities and how often the child asked to be read to include: 1=Not at all, 2=Once or twice per week, $3=$ Three to six times, 4=Every day. Missing values set at the sample average. 
Table A3: Randomization checks: The effect of treatment status on pre-treatment child covariates by year

\begin{tabular}{|c|c|c|c|c|}
\hline \multirow[t]{2}{*}{ Pre-treatment child covariates } & \multicolumn{2}{|c|}{$\begin{array}{l}\text { Parent Survey } \\
\text { Sample }\end{array}$} & \multicolumn{2}{|c|}{ Academic Sample } \\
\hline & Year 1 & Year 2 & Year 1 & Year 2 \\
\hline Child female & $\begin{array}{c}0.064 \\
(0.064)\end{array}$ & $\begin{array}{c}0.001 \\
(0.058)\end{array}$ & $\begin{array}{c}-0.002 \\
(0.058)\end{array}$ & $\begin{array}{l}-0.004 \\
(0.041)\end{array}$ \\
\hline Hispanic & $\begin{array}{l}-0.028 \\
(0.034)\end{array}$ & $\begin{array}{c}0.014 \\
(0.059)\end{array}$ & $\begin{array}{l}-0.055 \\
(0.034)\end{array}$ & $\begin{array}{c}-0.010 \\
(0.026)\end{array}$ \\
\hline Chinese & $\begin{array}{c}0.060 \\
(0.040)\end{array}$ & $\begin{array}{c}-0.029 \\
(0.037)\end{array}$ & $\begin{array}{c}0.023 \\
(0.024)\end{array}$ & $\begin{array}{c}0.041 \\
(0.029)\end{array}$ \\
\hline Black & $\begin{array}{c}0.028 \\
(0.040)\end{array}$ & $\begin{array}{c}0.015 \\
(0.023)\end{array}$ & $\begin{array}{c}0.025 \\
(0.025)\end{array}$ & $\begin{array}{l}-0.025 \\
(0.032)\end{array}$ \\
\hline White & $\begin{array}{c}-0.064 * \\
(0.030)\end{array}$ & $\begin{array}{l}-0.007 \\
(0.042)\end{array}$ & $\begin{array}{c}-0.017 \\
(0.019)\end{array}$ & $\begin{array}{c}0.001 \\
(0.034)\end{array}$ \\
\hline Other Race & $\begin{array}{c}0.028 \\
(0.035)\end{array}$ & $\begin{array}{c}-0.005 \\
(0.036)\end{array}$ & $\begin{array}{c}0.024 \\
(0.031)\end{array}$ & $\begin{array}{l}-0.007 \\
(0.028)\end{array}$ \\
\hline Child age in years & $\begin{array}{c}0.044 \\
(0.038)\end{array}$ & $\begin{array}{c}0.006 \\
(0.035)\end{array}$ & $\begin{array}{c}0.020 \\
(0.028)\end{array}$ & $\begin{array}{c}0.080 \\
(0.066)\end{array}$ \\
\hline Parent female & $\begin{array}{c}-0.030 \\
(0.031)\end{array}$ & $\begin{array}{c}-0.028 \\
(0.058)\end{array}$ & $\begin{array}{c}0.000 \\
(0.033)\end{array}$ & $\begin{array}{c}0.004 \\
(0.040)\end{array}$ \\
\hline Parent age in years & $\begin{array}{l}-0.811 \\
(0.614)\end{array}$ & $\begin{array}{c}0.741 \\
(0.850)\end{array}$ & $\begin{array}{l}-0.155 \\
(0.470)\end{array}$ & $\begin{array}{c}0.956 \\
(0.700)\end{array}$ \\
\hline Less than bachelor's degree & $\begin{array}{l}-0.074 \\
(0.045)\end{array}$ & $\begin{array}{c}-0.033 \\
(0.050)\end{array}$ & $\begin{array}{c}-0.089 * \\
(0.043)\end{array}$ & $\begin{array}{c}0.003 \\
(0.039)\end{array}$ \\
\hline Parent rating of letter knowledge (fall) & $\begin{array}{l}0.253^{*} \\
(0.109)\end{array}$ & $\begin{array}{c}0.087 \\
(0.107)\end{array}$ & $\begin{array}{c}0.068 \\
(0.104)\end{array}$ & $\begin{array}{l}-0.022 \\
(0.080)\end{array}$ \\
\hline Parent rating of how often child ask to be read to per week (fall) & $\begin{array}{c}-0.308^{*} \\
(0.137)\end{array}$ & $\begin{array}{c}-0.053 \\
(0.112)\end{array}$ & $\begin{array}{c}-0.195+ \\
(0.109)\end{array}$ & $\begin{array}{l}-0.056 \\
(0.079)\end{array}$ \\
\hline How many times per week parent reads for pleasure (fall) & $\begin{array}{l}-0.001 \\
(0.100)\end{array}$ & $\begin{array}{l}-0.031 \\
(0.123)\end{array}$ & $\begin{array}{c}0.045 \\
(0.089)\end{array}$ & $\begin{array}{l}-0.076 \\
(0.068)\end{array}$ \\
\hline How many times per week parent tells a story to child (fall) & $\begin{array}{l}-0.061 \\
(0.111)\end{array}$ & $\begin{array}{c}-0.040 \\
(0.136)\end{array}$ & $\begin{array}{l}-0.001 \\
(0.104)\end{array}$ & $\begin{array}{c}0.043 \\
(0.083)\end{array}$ \\
\hline How many times per week parent sings to child (fall) & $\begin{array}{l}-0.020 \\
(0.119)\end{array}$ & $\begin{array}{c}-0.019 \\
(0.122)\end{array}$ & $\begin{array}{c}0.017 \\
(0.079)\end{array}$ & $\begin{array}{c}-0.052 \\
(0.094)\end{array}$ \\
\hline Child literacy assessment sum score (fall; $\max =126.0$ ) & $\begin{array}{c}5.307 \\
(4.580)\end{array}$ & $\begin{array}{c}0.611 \\
(4.404)\end{array}$ & $\begin{array}{c}-2.122 \\
(3.564)\end{array}$ & $\begin{array}{c}-0.935 \\
(3.045)\end{array}$ \\
\hline Received texts in English & $\begin{array}{l}-0.005 \\
(0.032)\end{array}$ & $\begin{array}{c}-0.061 \\
(0.052)\end{array}$ & $\begin{array}{c}0.051 \\
(0.031)\end{array}$ & $\begin{array}{c}0.002 \\
(0.048)\end{array}$ \\
\hline Received texts in Spanish & $\begin{array}{l}-0.025 \\
(0.029)\end{array}$ & $\begin{array}{c}0.050 \\
(0.032)\end{array}$ & $\begin{array}{c}-0.049^{*} \\
(0.021)\end{array}$ & $\begin{array}{c}0.016 \\
(0.037)\end{array}$ \\
\hline Received texts in Chinese & $\begin{array}{c}0.030 \\
(0.021)\end{array}$ & $\begin{array}{c}0.010 \\
(0.046)\end{array}$ & $\begin{array}{c}-0.001 \\
(0.017)\end{array}$ & $\begin{array}{c}-0.018 \\
(0.033)\end{array}$ \\
\hline p-value of test of joint significance & 0.001 & 0.326 & 0.092 & 0.215 \\
\hline $\begin{array}{l}N= \\
\text { Randomization site-by-year fixed effects }\end{array}$ & 287 & 271 & 395 & 426 \\
\hline
\end{tabular}

Notes. Fall parent survey responses are standardized. Missing values are replaced with sample average.

Standard errors are clustered at the randomization site-by-year level. + indicates $\mathrm{p}<0.10,{ }^{*} \mathrm{p}<0.05,{ }^{*} \mathrm{p}<0.01$. 
Table A4: The effects of READY4K! on parents' text messaging behaviors and attitudes by year

\begin{tabular}{|c|c|c|c|}
\hline & Model 1 & Model 2 & $\mathrm{~N}$ \\
\hline \multicolumn{4}{|l|}{ Panel A. First year of experiment } \\
\hline Parent read text messages & $\begin{array}{c}0.202 \\
(0.128)\end{array}$ & $\begin{array}{l}0.248+ \\
(0.130)\end{array}$ & 279 \\
\hline Parent used text messages & $\begin{array}{c}0.504 * * \\
(0.147)\end{array}$ & $\begin{array}{c}0.538^{* *} \\
(0.158)\end{array}$ & 279 \\
\hline Parent found text messages helpful & $\begin{array}{c}0.523 * * \\
(0.143)\end{array}$ & $\begin{array}{c}0.613^{* *} \\
(0.138)\end{array}$ & 279 \\
\hline Parent shared texts with other parents & $\begin{array}{l}0.248^{*} \\
(0.113)\end{array}$ & $\begin{array}{l}0.277^{*} \\
(0.135)\end{array}$ & 281 \\
\hline Parent would recommend texts & $\begin{array}{l}0.238+ \\
(0.122)\end{array}$ & $\begin{array}{l}0.245+ \\
(0.135)\end{array}$ & 282 \\
\hline \multicolumn{4}{|l|}{ Panel B. Second year of experiment } \\
\hline Parent read text messages & $\begin{array}{c}0.095 \\
(0.152)\end{array}$ & $\begin{array}{c}0.066 \\
(0.182)\end{array}$ & 266 \\
\hline Parent used text messages & $\begin{array}{c}0.076 \\
(0.121)\end{array}$ & $\begin{array}{c}0.055 \\
(0.132)\end{array}$ & 266 \\
\hline Parent found text messages helpful & $\begin{array}{l}0.274+ \\
(0.124)\end{array}$ & $\begin{array}{l}0.233+ \\
(0.123)\end{array}$ & 262 \\
\hline Parent would recommend texts & $\begin{array}{c}0.372 * * \\
(0.135)\end{array}$ & $\begin{array}{c}0.383 * * \\
(0.136)\end{array}$ & 263 \\
\hline Randomization site-by-year fixed effects & $\checkmark$ & $\checkmark$ & \\
\hline Administrative and fall parent survey covariates & & $\checkmark$ & \\
\hline Fall literacy assessment covariates & & $\checkmark$ & \\
\hline
\end{tabular}

Notes. All outcomes are standardized by year. Standard errors are clustered at the randomization site-by-year level. Included covariates are detailed in Table 4. + indicates $p<0.10,{ }^{*} p<0.05$, $* * \mathrm{p}<0.01$. 
Table A5: Heterogeneity in READY4K! effects on children's spring early literacy assessment scores Sample of children above median of baseline skills

\begin{tabular}{|c|c|c|c|}
\hline Panel A. Average outcomes, first year of experiment & Model 1 & Model 2 & $\mathrm{~N}$ \\
\hline Average of all questions & $\begin{array}{c}-0.014 \\
(0.101)\end{array}$ & $\begin{array}{c}0.000 \\
(0.087)\end{array}$ & 197 \\
\hline Average of non-leveled questions & $\begin{array}{c}-0.056 \\
(0.098)\end{array}$ & $\begin{array}{l}-0.072 \\
(0.091)\end{array}$ & 197 \\
\hline \multicolumn{4}{|l|}{ Panel B. Average outcomes, second year of experiment } \\
\hline Average of all questions & $\begin{array}{l}-0.045 \\
(0.084)\end{array}$ & $\begin{array}{c}-0.073 \\
(0.070)\end{array}$ & 219 \\
\hline Average of non-leveled questions & $\begin{array}{c}-0.053 \\
(0.080)\end{array}$ & $\begin{array}{l}-0.078 \\
(0.073)\end{array}$ & 291 \\
\hline \multicolumn{4}{|l|}{ Panel C. All outcomes, pooled sample } \\
\hline Average of all questions & $\begin{array}{c}-0.031 \\
(0.063)\end{array}$ & $\begin{array}{l}-0.028 \\
(0.049)\end{array}$ & 416 \\
\hline Average of non-leveled questions & $\begin{array}{l}-0.054 \\
(0.062)\end{array}$ & $\begin{array}{l}-0.059 \\
(0.057)\end{array}$ & 416 \\
\hline Upper case letter recognition & $\begin{array}{l}-0.009 \\
(0.044)\end{array}$ & $\begin{array}{c}0.000 \\
(0.044)\end{array}$ & 414 \\
\hline Beginning word sound awareness & $\begin{array}{c}0.033 \\
(0.074)\end{array}$ & $\begin{array}{c}0.032 \\
(0.077)\end{array}$ & 408 \\
\hline Print and word awareness & $\begin{array}{c}-0.061 \\
(0.085)\end{array}$ & $\begin{array}{l}-0.083 \\
(0.087)\end{array}$ & 410 \\
\hline Rhyme awareness & $\begin{array}{c}-0.069 \\
(0.088)\end{array}$ & $\begin{array}{l}-0.068 \\
(0.087)\end{array}$ & 406 \\
\hline Name writing & $\begin{array}{l}-0.068 \\
(0.059)\end{array}$ & $\begin{array}{l}-0.071 \\
(0.059)\end{array}$ & 415 \\
\hline Probability of progressing to leveled portion of assessment & $\begin{array}{l}-0.012 \\
(0.029)\end{array}$ & $\begin{array}{c}0.001 \\
(0.032)\end{array}$ & 416 \\
\hline Lower case letter recognition & $\begin{array}{c}-0.004 \\
(0.085)\end{array}$ & $\begin{array}{c}0.028 \\
(0.093)\end{array}$ & 401 \\
\hline Letter sounds awareness & $\begin{array}{c}0.035 \\
(0.092)\end{array}$ & $\begin{array}{c}0.012 \\
(0.085)\end{array}$ & 387 \\
\hline Randomization site-by-year fixed effects & $\checkmark$ & $\checkmark$ & \\
\hline Administrative and fall parent survey covariates & & $\checkmark$ & \\
\hline Fall literacy assessment covariates & & $\checkmark$ & \\
\hline
\end{tabular}

Notes. All outcomes are standardized by year. Standard errors are clustered at the randomization site-by-year level. Included covariates are detailed in Table $4 .+$ indicates $\mathrm{p}<0.10, * \mathrm{p}<0.05, * * \mathrm{p}<0.01$. 
Table A6: Composite Variable Components

Panel A. Global home literacy composite variable, first year of experiment

Components:

Scoring

coefficient

Pointed out letters in the home environment

0.14504

Pointed out two words that begin with the same sound to your child

0.16495

Pointed out two words that rhyme to your child

0.16637

Said \& explained a new word to your child using household objects

0.13605

Showed your child the different parts of a book (e.g., cover, title, author, and pages)

0.15588

Looked at pictures in a book with your child

0.14262

Showed or helped your child write his/her name

0.12261

Read to your child

0.13943

Told your child a story

0.13814

Recited a nursery rhyme to your child

0.13414

Eigenvalue: 4.74785 (47.48\% of variance explained)

Panel B. Global home literacy composite variable, second year of experiment

Scoring coefficient

Pointed out letters to your child

0.1846

Practiced word sounds with your child

0.2064

Practiced rhyming with your child

0.18928

Helped your child learn new words

0.19162

Showed your child the different parts of a book (e.g., cover, title, author, and pages)

0.17219

Showed your child we read from left to right

0.17254

Worked on literacy skills during family activities (meals, kitchen, etc...)

0.19908

Eigenvalue: 4.02786 (57.54\% of variance explained)

Panel C. Global parental involvement composite variable

Components:

Scoring

coefficient

Parent asked about their child's interests

0.14285

Parent asked about their child's friends

0.14226

Parent asked about how the child gets along with others

0.13665

Parent asked about what their child is doing in school

0.14187

Parent asked about what their child is learning in school

0.14577

Parent asked about their child's understanding of early literacy skills like the ABCs

0.14249

Parent asked about things they can do to help their child learn to read

0.14194

Parent asked for book recommendations

0.12035

Eigenvalue: 6.42564 (80.32\% of variance explained) 
Table A7: Randomization checks: Differential attrition by covariate (combined sample)

\begin{tabular}{|c|c|c|c|}
\hline Pre-treatment covariates & $\begin{array}{l}\text { Parent } \\
\text { Survey } \\
\text { Sample }\end{array}$ & $\begin{array}{l}\text { Teacher } \\
\text { Survey } \\
\text { Sample }\end{array}$ & $\begin{array}{c}\text { Academic } \\
\text { Sample }\end{array}$ \\
\hline Child female $\mathrm{x}$ treatment & $\begin{array}{c}0.039 \\
(0.060)\end{array}$ & $\begin{array}{c}0.016 \\
(0.039)\end{array}$ & $\begin{array}{c}0.009 \\
(0.055)\end{array}$ \\
\hline Hispanic $\mathrm{x}$ treatment & $\begin{array}{l}-0.018 \\
(0.072)\end{array}$ & $\begin{array}{c}0.031 \\
(0.038)\end{array}$ & $\begin{array}{l}-0.011 \\
(0.049)\end{array}$ \\
\hline Chinese $\mathrm{x}$ treatment & $\begin{array}{c}0.022 \\
(0.073)\end{array}$ & $\begin{array}{l}-0.039 \\
(0.036)\end{array}$ & $\begin{array}{l}-0.007 \\
(0.040)\end{array}$ \\
\hline Black x treatment & $\begin{array}{l}-0.026 \\
(0.088)\end{array}$ & $\begin{array}{c}0.067 \\
(0.078)\end{array}$ & $\begin{array}{c}0.103 \\
(0.081)\end{array}$ \\
\hline White $\mathrm{x}$ treatment & $\begin{array}{l}-0.136 \\
(0.132)\end{array}$ & $\begin{array}{c}0.014 \\
(0.053)\end{array}$ & $\begin{array}{c}0.031 \\
(0.063)\end{array}$ \\
\hline Other Race $\mathrm{x}$ treatment & $\begin{array}{c}0.114 \\
(0.105)\end{array}$ & $\begin{array}{l}-0.058 \\
(0.052)\end{array}$ & $\begin{array}{l}-0.064 \\
(0.090)\end{array}$ \\
\hline Child age in years $x$ treatment & $\begin{array}{c}0.080 \\
(0.097)\end{array}$ & $\begin{array}{c}0.013 \\
(0.073)\end{array}$ & $\begin{array}{c}0.090 \\
(0.071)\end{array}$ \\
\hline Parent female $\mathrm{x}$ treatment & $\begin{array}{c}-0.151+ \\
(0.083)\end{array}$ & $\begin{array}{c}0.064 \\
(0.052)\end{array}$ & $\begin{array}{c}-0.155^{*} \\
(0.065)\end{array}$ \\
\hline Parent age in years $\mathrm{x}$ treatment & $\begin{array}{l}-0.002 \\
(0.005)\end{array}$ & $\begin{array}{l}-0.002 \\
(0.003)\end{array}$ & $\begin{array}{c}0.000 \\
(0.004)\end{array}$ \\
\hline Less than bachelor's degree $\mathrm{x}$ treatment & $\begin{array}{l}-0.124 \\
(0.075)\end{array}$ & $\begin{array}{c}0.015 \\
(0.042)\end{array}$ & $\begin{array}{l}-0.068 \\
(0.066)\end{array}$ \\
\hline Parent rating of letter knowledge (fall) $\mathrm{x}$ treatment & $\begin{array}{l}0.075^{*} \\
(0.035)\end{array}$ & $\begin{array}{c}0.010 \\
(0.018)\end{array}$ & $\begin{array}{c}0.018 \\
(0.027)\end{array}$ \\
\hline How often child ask to be read to per week (fall) $\mathrm{x}$ treatment & $\begin{array}{l}-0.006 \\
(0.036)\end{array}$ & $\begin{array}{c}0.007 \\
(0.014)\end{array}$ & $\begin{array}{c}0.036 \\
(0.029)\end{array}$ \\
\hline How many times per week parent reads for pleasure (fall) $\mathrm{x}$ treatment & $\begin{array}{l}-0.005 \\
(0.031)\end{array}$ & $\begin{array}{c}0.023 \\
(0.018)\end{array}$ & $\begin{array}{c}0.016 \\
(0.027)\end{array}$ \\
\hline How many times per week parent tells a story to child (fall) $\mathrm{x}$ treatment & $\begin{array}{l}-0.008 \\
(0.031)\end{array}$ & $\begin{array}{c}0.007 \\
(0.017)\end{array}$ & $\begin{array}{c}0.041 \\
(0.026)\end{array}$ \\
\hline How many times per week parent sings to child (fall) $\mathrm{x}$ treatment & $\begin{array}{c}0.024 \\
(0.032)\end{array}$ & $\begin{array}{c}0.024 \\
(0.021)\end{array}$ & $\begin{array}{c}0.032 \\
(0.028)\end{array}$ \\
\hline Child literacy assessment sum score (fall; $\max =126.0) \times$ treatment & $\begin{array}{c}0.002 \\
(0.001)\end{array}$ & $\begin{array}{c}0.000 \\
(0.000)\end{array}$ & $\begin{array}{c}0.000 \\
(0.001)\end{array}$ \\
\hline Received texts in English $\mathrm{x}$ treatment & $\begin{array}{l}-0.011 \\
(0.059)\end{array}$ & $\begin{array}{l}-0.001 \\
(0.038)\end{array}$ & $\begin{array}{c}0.054 \\
(0.047)\end{array}$ \\
\hline Received texts in Spanish $\mathrm{x}$ treatment & $\begin{array}{l}-0.017 \\
(0.070)\end{array}$ & $\begin{array}{c}0.008 \\
(0.046)\end{array}$ & $\begin{array}{c}-0.032 \\
(0.056)\end{array}$ \\
\hline Received texts in Chinese $\mathrm{x}$ treatment & $\begin{array}{c}0.031 \\
(0.066)\end{array}$ & $\begin{array}{l}-0.008 \\
(0.044)\end{array}$ & $\begin{array}{l}-0.047 \\
(0.056)\end{array}$ \\
\hline $\begin{array}{l}\text { Model inclusions: } \\
\text { Randomization site-by-year fixed effects }\end{array}$ & $\checkmark$ & $\checkmark$ & $\checkmark$ \\
\hline
\end{tabular}

Notes. Fall parent survey responses are standardized. Standard errors are clustered at the randomization siteby-year level. Sample size varies by covariate due to missing data. The average sample size is 989 and the maximum sample size is 1,031 . Standard errors are clustered at the randomization site-by-year level. + indicates $\mathrm{p}<0.10,{ }^{*} \mathrm{p}<0.05,{ }^{*} \mathrm{p}<0.01$. 
Table A8: Effects of follow-up intervention on academic outcomes for students in the first year of original experiment, by median of baseline skills distribution

\begin{tabular}{lcc}
\hline \hline & $(1)$ & $(2)$ \\
\cline { 2 - 3 } & General Text & $\begin{array}{c}\text { Personalized Text } \\
\text { Treatment }\end{array}$ \\
\hline Panel A: Below Median of Baseline Skills (N=165) & & \\
\hline Reading level (ordinal logit) & 0.5437 & 0.6644 \\
& $(0.6224)$ & $(0.4397)$ \\
Reading level (standardized point scale) & 0.1414 & 0.1426 \\
Exceeds Expectations & $(0.1316)$ & $(0.1253)$ \\
& 0.0739 & $0.1628^{*}$ \\
Meets or Exceeds Expectations & $(0.0764)$ & $(0.0735)$ \\
& 0.148 & 0.148 \\
Approaches, Meets, or Exceeds Expectations & $(0.1012)$ & $(0.1012)$ \\
& 0.1727 & 0.0261 \\
Panel B: Above Median of Baseline Skills (N=166) & $(0.1415)$ & $(0.1114)$ \\
\hline Reading level (ordinal logit) & & 0.4734 \\
Reading level (standardized point scale) & -0.6473 & $(0.3280)$ \\
& $(0.5700)$ & 0.2114 \\
Exceeds Expectations & -0.0168 & $(0.2254)$ \\
Meets or Exceeds Expectations & $(0.2394)$ & 0.0645 \\
& 0.0045 & $(0.0726)$ \\
Approaches, Meets, or Exceeds Expectations & $(0.1117)$ & 0.0714 \\
& -0.1269 & $(0.0664)$ \\
\hline \hline
\end{tabular}

Note: Each pair of cells represents the results of a separate regression of the treatment effect on the relevant academic outcome. Column headers indicate the model components. The reference category is the control group. Row headers indicate the academic outcome. Panel headers indicate the subsample. All models include site fixed effects, control for text message language, factors of baseline survey questions, and administrative covariates. Source data are district test files of the Fountas and Pinnell Benchmark Assessment System in fall of first grade. Baseline skills were calculated from performance on the Phonological Awareness Literacy Screening administered in fall of 2013. Standard errors are clustered by randomization site. +indicates $\mathrm{p}<0.10,{ }^{*} \mathrm{p}<0.05, * * \mathrm{p}<0.01$, $* * * p<0.001$ 